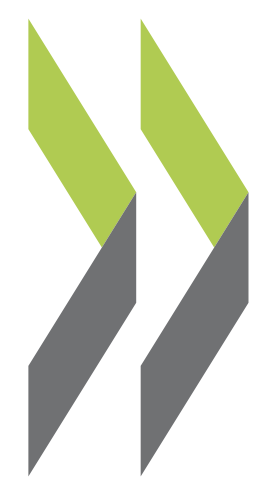

OECD Economics Department Working Papers No. 838 Raising Education Outcomes in Switzerland Andrés Fuentes 
Organisation de Coopération et de Développement Économiques

Organisation for Economic Co-operation and Development

02-Feb-2011

ECONOMICS DEPARTMENT

English - Or. English

RAISING EDUCATION OUTCOMES IN SWITZERLAND

ECONOMICS DEPARTMENT WORKING PAPER No. 838

By Andrés Fuentes

All Economics Department Working Papers are available on the OECD's Intranet website at www.oecd/eco/workingpapers

JT03295846

Document complet disponible sur OLIS dans son format d'origine

Complete document available on OLIS in its original format 


\title{
ABSTRACT/RÉSUMÉ \\ Raising education outcomes in Switzerland
}

\begin{abstract}
Almost all workers are educated at least to the upper secondary level and vocational education contributes to one of the most successful transition performances of youth to employment in the OECD. Higher education enjoys an excellent reputation, as reflected in one of the highest scientific publication rates relative to population in the OECD and high placements of Swiss universities in international rankings. Participation in continuous education is among the largest in the OECD. Results for children with low socio-economic background or immigration background do not fully measure up to the high standards of the education system. Improving early childhood education and availability of childcare facilities for very young children would raise subsequent educational attainment, especially for these groups of children. Accountability of schools for their education outcomes should be raised. In tertiary education, attainment rates among the young are modest for a highincome OECD country, reflecting the importance of the upper secondary vocational system. A larger supply of tertiary graduates could have benefits for productivity performance especially in the context of demographic ageing. Public spending per pupil on pre-primary education is low in international comparison whereas spending on tertiary academic education per graduate is among the highest in the OECD.
\end{abstract}

JEL classification: I21, I22, I23, I28

Keywords: Switzerland; education; pre-school education; compulsory education; tertiary education; university education; education funding.

$$
+++
$$

\section{Améliorer les résultats de l'enseignement en Suisse}

Presque tous les travailleurs ont un niveau d'instruction correspondant au moins au deuxième cycle de l'enseignement secondaire, et l'enseignement professionnel contribue à assurer aux jeunes un passage à l'emploi parmi les plus réussis de la zone de l'OCDE. L'enseignement supérieur jouit d'une excellente réputation, comme en témoignent le taux de publications scientifiques par rapport à la population, l'un des plus élevés de la zone de l'OCDE, et le rang élevé qu'occupent les universités helvétiques dans les classements internationaux. La participation à la formation continue est l'une des plus fortes de la zone de l'OCDE. Les résultats relevés pour les enfants de milieu socio-économique modeste ou issus de l'immigration ne sont pas vraiment à la hauteur de la qualité du système d'enseignement. Améliorer l'éducation préscolaire et l'offre de structures d'accueil des très jeunes enfants permettrait à ces derniers, surtout aux deux catégories d'enfants précitées, de mieux réussir dans leur scolarité ultérieure. Dans l'enseignement obligatoire les établissements devraient être tenus plus responsables de leurs résultats. En ce qui concerne l'enseignement supérieur, les taux de diplômés enregistrés parmi les jeunes sont peu élevés pour un pays de l'OCDE à haut revenu, ce qui tient à l'importance de la filière professionnelle du deuxième cycle de l'enseignement secondaire. Une augmentation du nombre de diplômés de l'enseignement supérieur pourrait se traduire par des gains de productivité, surtout face au vieillissement de la population. Les dépenses publiques par élève de l'enseignement préscolaire sont faibles par comparaison avec les autres pays, alors que les dépenses par diplômé de l'enseignement supérieur universitaire figurent parmi les plus élevées de la zone de l'OCDE. Certaines données d'observation montrent qu'une augmentation de l'offre de travailleurs ayant fait des études supérieures ferait croître la productivité, qui est en moyenne inférieure à celle des autres pays de l'OCDE jouant un rôle de premier plan et progresse faiblement en Suisse depuis dix ans.

Codes JEL I21, I22, I23, I28

Mots Clés : Suisse; éducation; éducation préscolaire; éducation obligatoire; éducation supérieure; éducation universitaire ; financement de l'éducation.

Copyright $($ O OECD, 2011. All rights reserved. Application for permission to reproduce or translate all, or part of, this material should be made to: Head of Publications Service, OECD, 2 rue André-Pascal, 75775 PARIS CEDEX 16, France. 


\section{Table of contents}

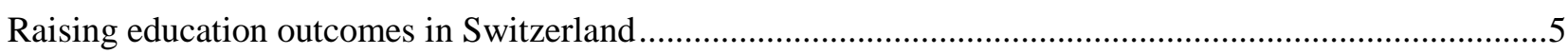

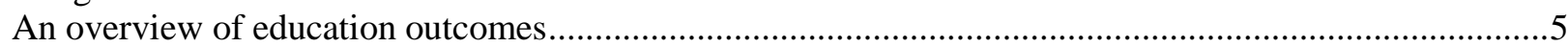

Outcomes at the end of compulsory education are strong but depend on socio-economic background ..5

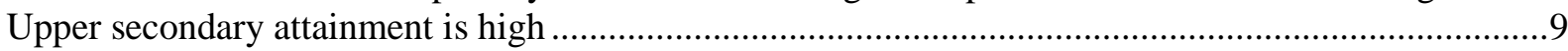

Tertiary attainment among young workers is modest while private returns are high ...........................10

The transition to the labour market of upper secondary and tertiary graduates is excellent .................12

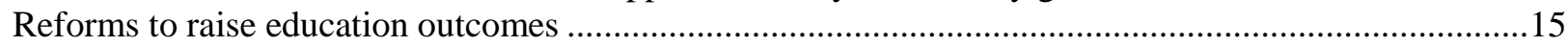

Public spending is relatively low on education of very young children..............................................15

Improving the contribution of pre-primary education to outcomes ......................................................18

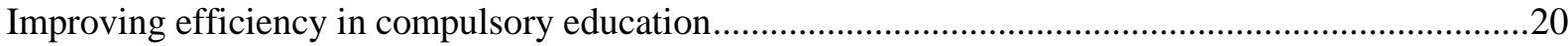

Policy reforms are underway in tertiary academic education ...........................................................2

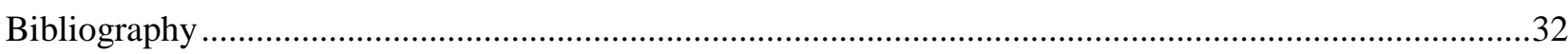

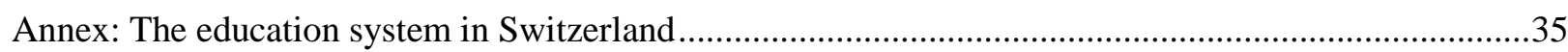

\section{Boxes}

1. The universities of applied science (hautes écoles spécialisées) ......................................................11

2. Assignment of responsibilities across levels of government ...........................................................21

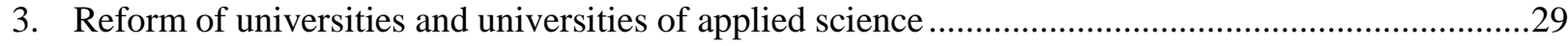

\section{Tables}

1. Differences in science Performance between students with an immigrant background and native 8 students

2. Trends in the percentage of the youth population in education and not in education........................13

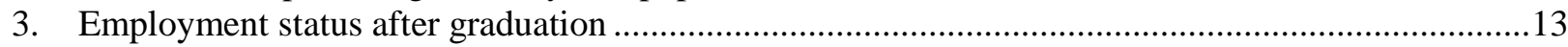

\section{Figures}

1. PISA scores in selected OECD countries: overall average scores and average scores for .................6 pupils with a less advantaged economic, social and cultural status.....

2. PISA science score controlling for GDP per capita and education attainment in the parent

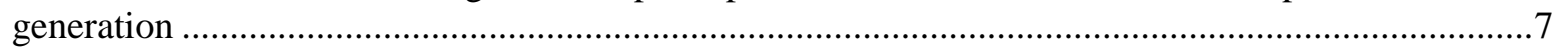

3. Learning outcomes for immigrant and native students compared ................................................

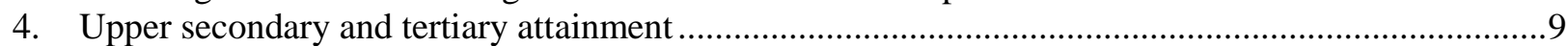

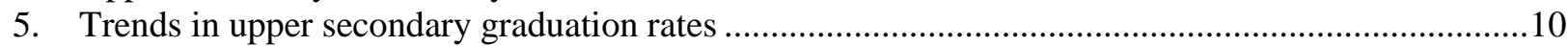

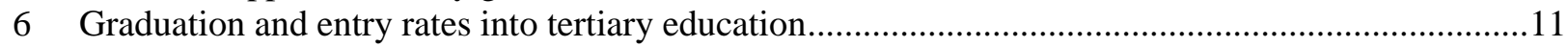

7. Estimates of the private internal rates of return to tertiary education ..............................................12

8. Male employment by educational attainment (2006) …..............................................................14

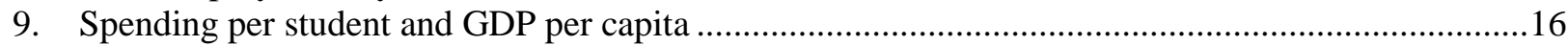

10. Cumulative spending per student in tertiary education, 2006 .......................................................17

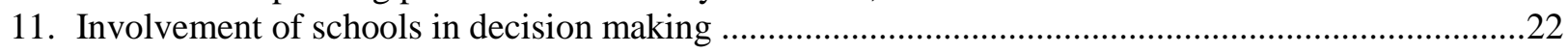

12. Expenditure per pupil on primary education and GDP per capita across cantons .............................24 
ECO/WKP(2011)7 
ECO/WKP(2011)7

\title{
RAISING EDUCATION OUTCOMES IN SWITZERLAND
}

\author{
By Andrés Fuentes ${ }^{1}$
}

\section{An overview of education outcomes}

\section{Outcomes at the end of compulsory education are strong but depend on socio-economic background}

In the Programme for International Student Assessment (PISA), Swiss pupils reached higher average scores than their peers in most OECD countries, ranking among the top performers in mathematics, even though a relatively large share of teaching hours in Switzerland is devoted to the teaching of non-native languages. However, results are less favourable, in comparison with OECD countries with the highest GDP per capita, for pupils with modest socio-economic background (Figure 1 ). ${ }^{2}$ Indeed, the impact of socioeconomic background on education outcomes is stronger than on average in the OECD, especially with respect to the educational attainment of the parent, although it is not quite as marked as in other countries in which pupils are placed in different tracks in lower secondary schools. The impact of parental socioeconomic background on student performance is stronger if the pupils attend different schools than if they attend the same school (OECD, 2007b). At the same time, participation of students in different study programmes contributes considerably less to explaining variation in PISA scores than in other countries practicing early tracking (OECD, 2007b). Also, controlling for the positive influence average educational attainment and income per capita have on PISA scores across countries, the results may compare less favourably internationally (see Figure 2, which uses a simple, rough method to control for such influences on science scores), including in comparison with some OECD countries with highest per capita incomes. Results are weaker yet in reading.

1. Senior economist in the Economics Department. This paper was originally prepared for the OECD's 2009 Economic Survey of Switzerland under the responsibility of the Economic and Development Review Committee. The paper benefited from suggestions and comments by Paulo Santiago, Richard Yelland and Kathrin Höckel in the Education Department as well as from Andrew Dean, Robert Ford and Pierre Beynet in the Economics Department. Patrizio Sicari contributed statistical analysis. Special thanks to Sylvie Ricordeau, Véronique Henriksson and Maartje Michelson for editorial assistance.

2. The PISA index of socio-economic background takes is a composite index taking into account parental account educational attainment and occupation as well as cultural possessions at home. 
Figure 1. PISA scores in selected OECD countries: overall average scores and average scores for pupils with a less advantaged economic, social and cultural status ${ }^{1}$

\section{Mathematics, reading and science}
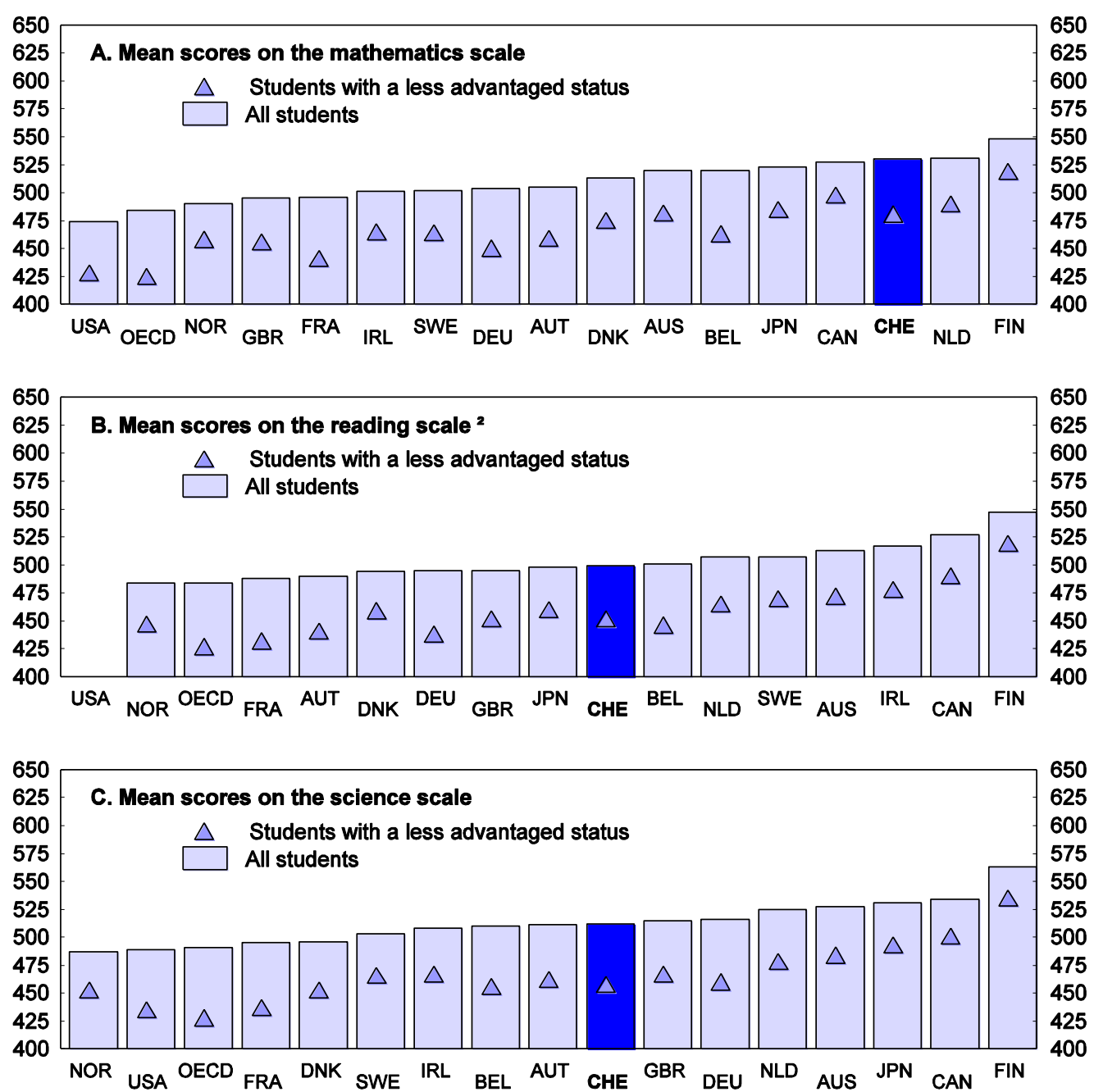

1. Students with a less advantaged status are the bottom quarter of the PISA index of economic, social and cultural status.

2. Data for the United States on the reading scale have not been published.

Source: OECD, PISA 2006. 
Figure 2. PISA science score controlling for GDP per capita and education attainment in the parent generation 1

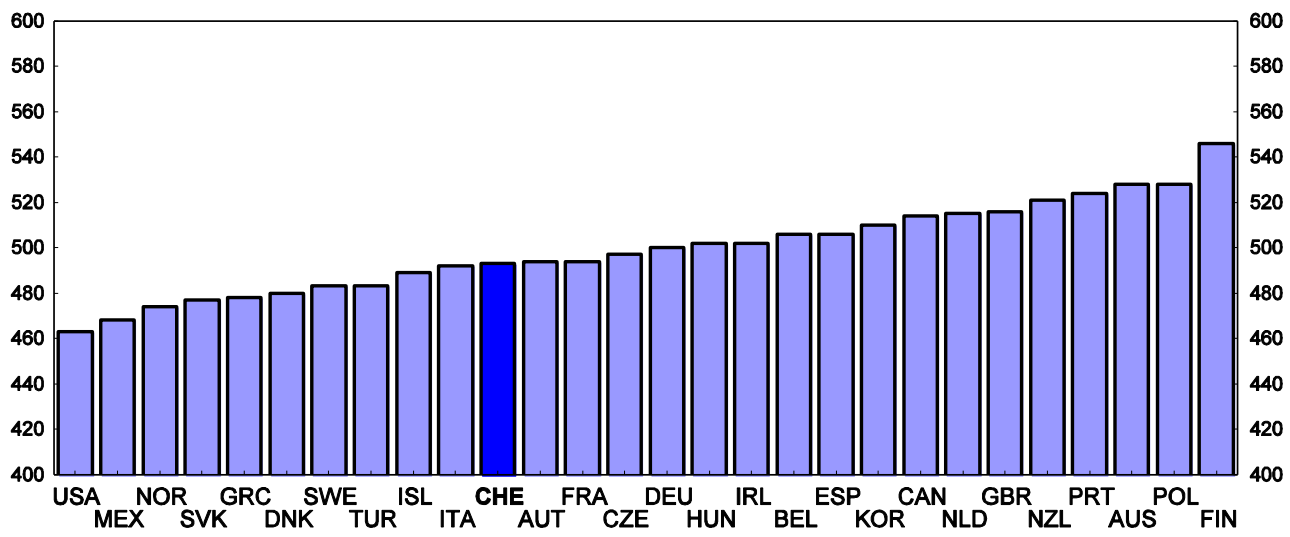

1. Science performance adjusted by GDP per capita and the percentage of the age group 35-44 years with upper secondary attainment.

Source: OECD, PISA 2006.

The education outcomes achieved at the end of compulsory education differ considerably across cantons. These gaps are likely to be related to the strong differences across cantons with respect to sociodemographic characteristics and the share of immigrants in their populations. Cantons also differ considerably regarding the impact of socio-economic background on PISA performance.

The difference between the performance of native and first-generation immigrant children is among the highest in the OECD. Integrating children with immigration background at school is particularly important as well as particularly challenging, as they make up a large share of pupils: $22 \%$ of 15 year-olds have immigration background (Figure 3). The shortfall in PISA results is particularly large for children who do not speak the language of instruction at home. More than half of children with immigration background or their parents originate from countries in which none of the Swiss official languages is spoken. Their weaker socio-economic status, relative to native children, also contributes to explaining the weaker results for immigrant children. However, some countries with similar average gaps in socioeconomic background between native and immigrant children succeed in limiting performance differences more strongly than Switzerland, such as France, Greece, Norway, Sweden, and the United States (OECD, 2007a). Moreover, immigrant youth also perform considerably less strongly than native children with a similar socio-economic background, regardless of whether or not they are native speakers of the local language (Table 1). 
Figure 3. Learning outcomes for immigrant and native students compared Average for reading, mathematics and science scales, PISA $2006^{1}$

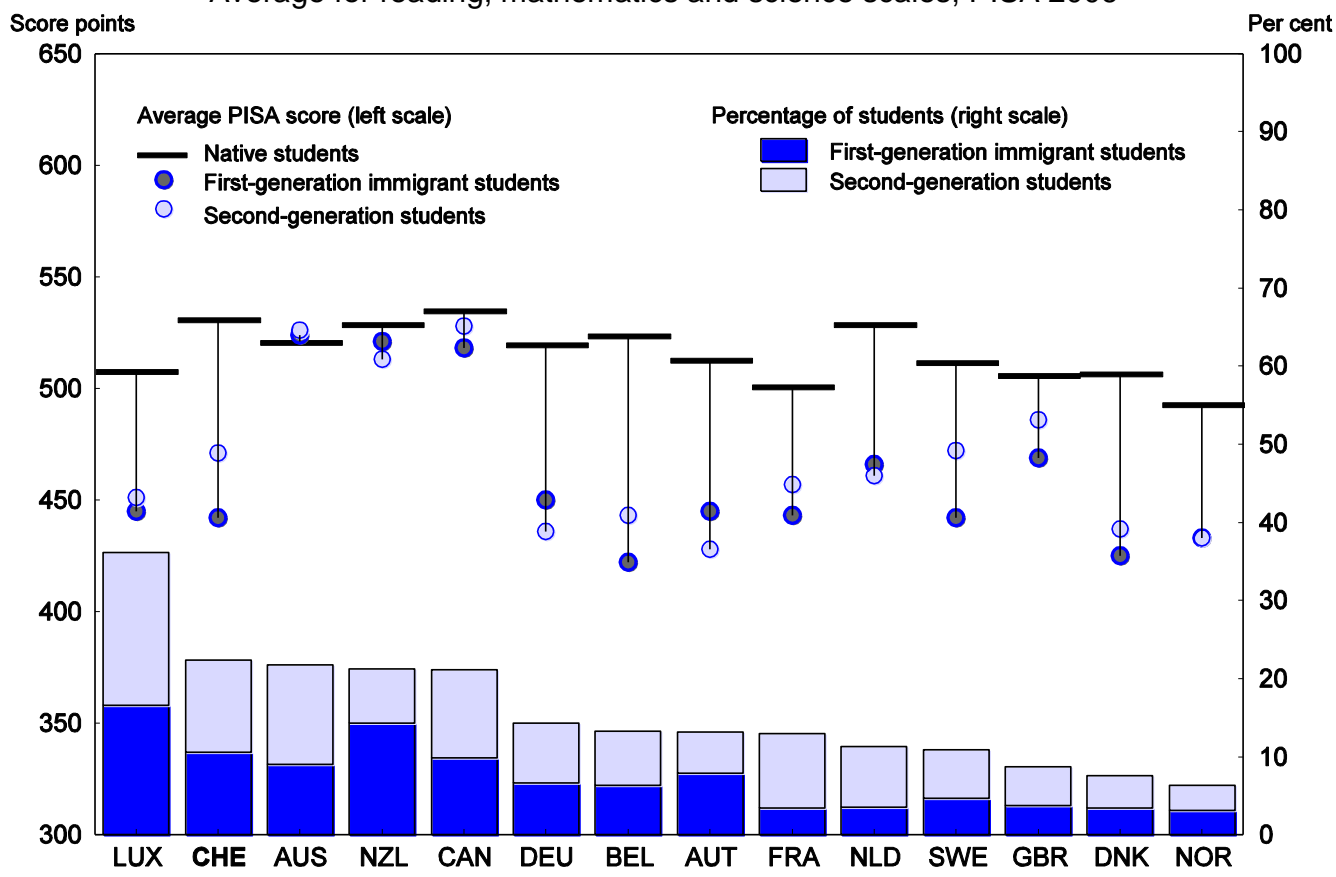

1. Only including countries with at least $3 \%$ of students in each category.

Source: OECD, PISA Results 2006.

Table 1. Differences in science performance between students with an immigrant background and native students

\begin{tabular}{|c|c|c|c|c|}
\hline & \multicolumn{2}{|c|}{$\begin{array}{l}\text { Students with an immigrant background minus } \\
\text { native students }\end{array}$} & \multicolumn{2}{|c|}{$\begin{array}{c}\text { Students with an immigrant background who speak } \\
\text { a language at home that is different from the } \\
\text { language of instruction } \\
\text { minus native students }\end{array}$} \\
\hline & $\begin{array}{l}\text { Without accounting } \\
\text { for the economic, } \\
\text { social and cultural } \\
\text { status of students }\end{array}$ & $\begin{array}{l}\text { With accounting for the } \\
\text { economic, social and } \\
\text { cultural status of students }\end{array}$ & $\begin{array}{l}\text { Without accounting } \\
\text { for the economic, } \\
\text { social and cultural } \\
\text { status of students }\end{array}$ & $\begin{array}{l}\text { With accounting for the } \\
\text { economic, social and } \\
\text { cultural status of } \\
\text { students }\end{array}$ \\
\hline Australia & -2.0 & -0.4 & -15.2 & 3.0 \\
\hline Austria & -90.1 & -60.9 & -96.4 & -36.8 \\
\hline Belgium & -86.4 & -57.2 & -102.4 & -51.8 \\
\hline Canada & -16.9 & -12.8 & -20.7 & -10.1 \\
\hline Denmark & -86.9 & -48.9 & -95.7 & -33.3 \\
\hline France & -53.1 & -18.1 & -58.8 & -18.2 \\
\hline Germany & -85.4 & -45.8 & -96.9 & -24.3 \\
\hline Greece & -44.3 & -25.1 & -78.9 & -10.4 \\
\hline Ireland & -10.5 & -12.8 & $\ldots$ & $\ldots$ \\
\hline Italy & -58.4 & -46.9 & $\ldots$ & $\ldots$ \\
\hline Luxembourg & -66.5 & -31.7 & -82.3 & 0.0 \\
\hline Netherlands & -75.5 & -41.0 & -85.6 & -36.9 \\
\hline New Zealand & -15.9 & -16.7 & -38.6 & -7.4 \\
\hline Norway & -58.6 & -35.3 & -59.8 & -24.0 \\
\hline Portugal & -54.9 & -56.5 & $\ldots$ & $\ldots$ \\
\hline Spain & -59.7 & -48.2 & $\ldots$ & $\ldots$ \\
\hline Sweden & -60.8 & -43.4 & -67.6 & -32.0 \\
\hline Switzerland & -81.4 & -56.3 & -95.5 & -37.2 \\
\hline United Kingdom & -32.5 & -14.2 & -49.1 & -8.3 \\
\hline United States & -48.3 & -16.8 & -62.2 & -9.5 \\
\hline OECD average & -54.4 & -34.4 & -69.1 & -21.1 \\
\hline
\end{tabular}

Source: OECD (2007b). 


\section{Upper secondary attainment is high}

Around $90 \%$ of 25 to 34 year olds have obtained an upper secondary degree, considerably more than the OECD average (Figure 4). Immigrant youth contribute a large share of youth who leave full-time education without an upper secondary degree. Almost $30 \%$ of the immigrant population do not possess an upper secondary degree, compared to less than $10 \%$ of natives, regardless of whether or not they completed compulsory schooling in Switzerland.

Most youth completing upper secondary education obtain a degree in the dual vocational system, which, in most cases, combines workplace-based, vocational training with 1-2 days per week of schoolbased general education, (see Hoeckel et al., 2009 for a detailed description) although a small minority do so through entirely school-based education (écoles de culture générale, see Annex). Almost $60 \%$ of students in upper secondary education pursue combined school and work - based education, more than in any other OECD country. On the other hand, the share of pupils pursuing a course that prepares for entry into tertiary academic education (maturité) is the lowest, at around 30\%. Most apprenticeship certificates take 3-4 years to complete, similar to general upper secondary education, which takes 3 years.

Figure 4. Upper secondary and tertiary attainment

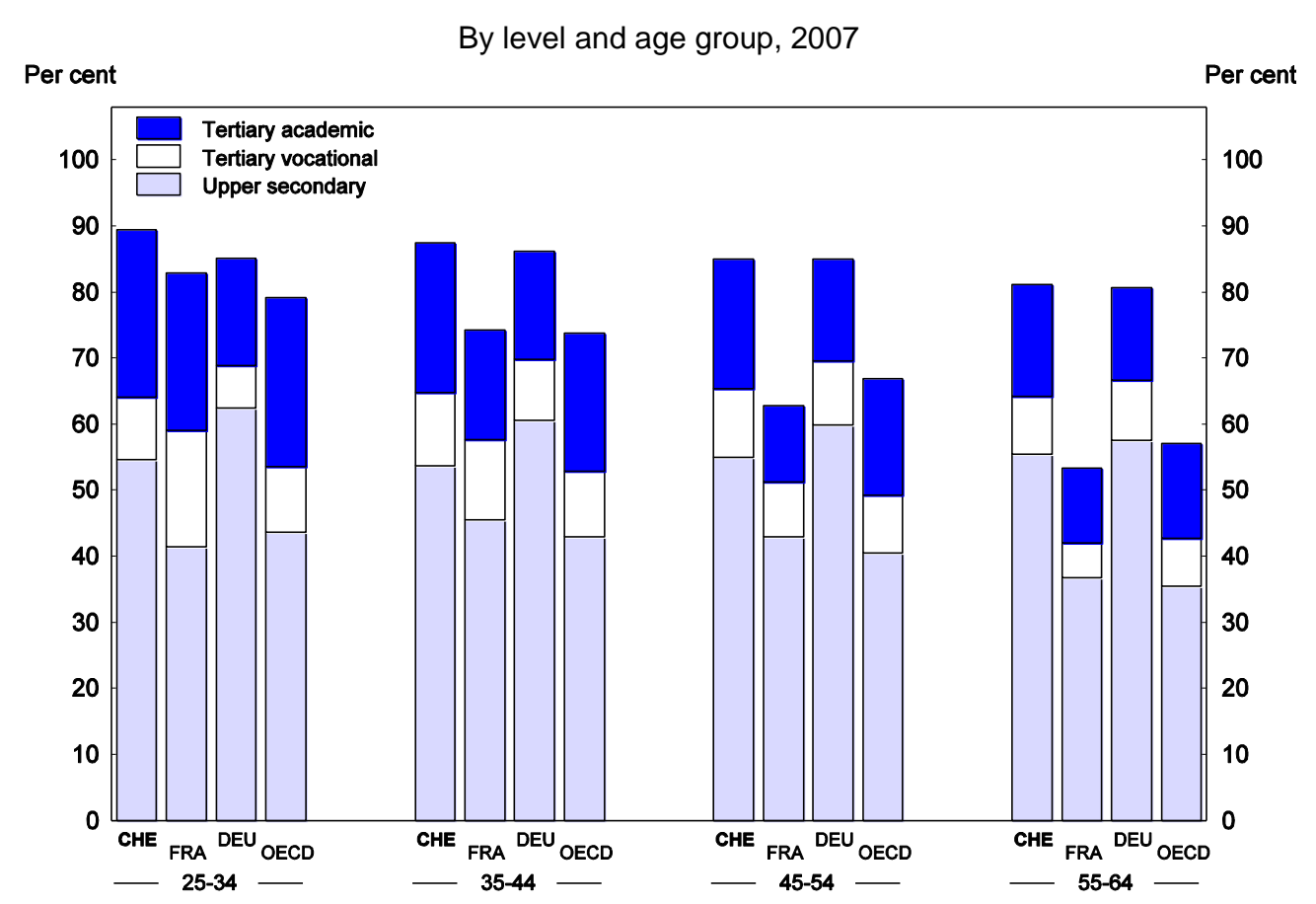

Source: OECD, Education at a Glance (2009).

The share of pupils obtaining an upper secondary qualification which prepares for entry into tertiary academic education (maturité) has risen gradually over time (Figure 5), although this trend has flattened in recent years. Much of the rise is accounted for by the introduction of the maturité professionelle at the end of 1990s (Figure 5). This degree offers graduates with vocational degrees a pathway towards tertiary academic education institutions introduced at the same time, namely the universities of applied science (see further below). In order to acquire the maturité professionelle, apprentices attend additional general education courses. About a third of graduates from the maturité professionelle decide to take the degree after completing their vocational degree, which contributes to a relatively high average age of graduation (21 years, see OFS, 2009). 


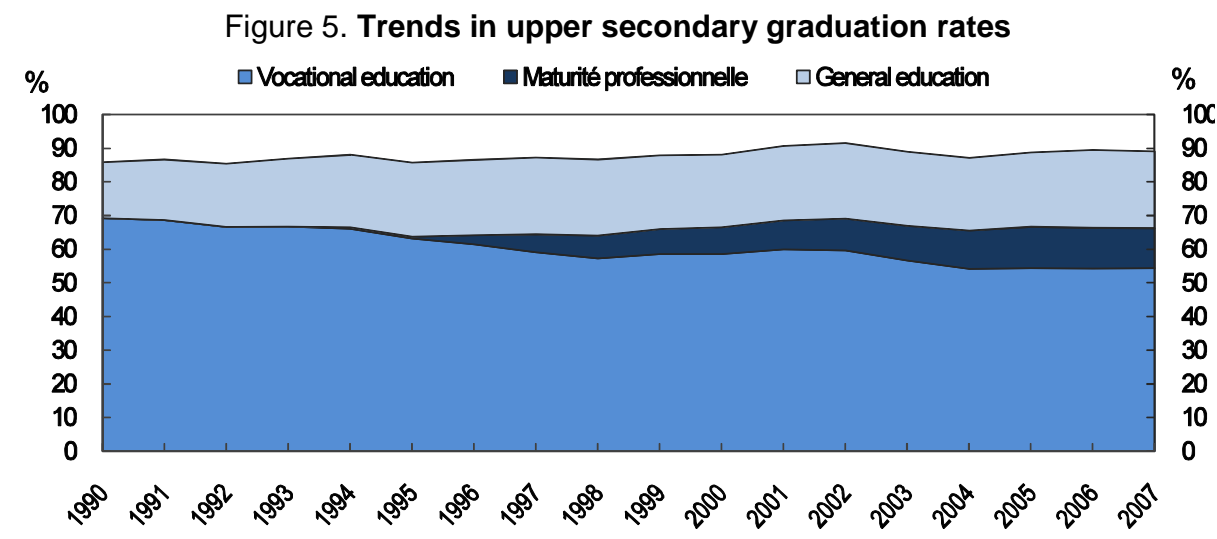

Source: Swiss Federal Statistical Office.

About a quarter of the students who pursue the vocational track in upper secondary obtain a maturité professionelle. Of these, most move on to the universities of applied science. In addition, roughly $20 \%$ of vocational secondary graduates eventually enter tertiary vocational education. By contrast, almost all pupils who complete the general track in upper secondary education move on to university.

\section{Tertiary attainment among young workers is modest while private returns are high}

Tertiary attainment for the population of working age is above the OECD average though below it among 25 to 34 year olds (Figure 4), as tertiary attainment has expanded more slowly in Switzerland than elsewhere in the OECD. Tertiary graduation rates have risen more markedly since 2000 in academic tertiary education institutions (ISCED 5A, see Figure 5.6; this includes universities and the universities of applied science, described in Box 1). The creation of the universities of applied science (hautes écoles specialisées) is the main contributing factor, although it has in part been offset by a decline in tertiary vocational degrees. The related increase of degrees preparing for the universities of applied sciences as well as the number of students taking up studies in these universities has flattened (Figures 5 and 6). Graduation rates have also been temporarily boosted by the introduction of the 2-tier degree structure in universities and universities of applied science (OFS, 2009b), as not all students who enrolled in the previous one-tier system have graduated yet. ${ }^{3}$ Overall entry rates into tertiary academic education have levelled off since 2003, although some effect of the improving business cycle at the time may also have played a role. These trends suggest that the increase in tertiary academic graduation rates observed in recent years will level off, as projected by the Federal Statistics Office and that tertiary attainment will remain below the rates seen in most other high-income OECD countries in the foreseeable future.

As in other OECD countries, high parental educational attainment raises the probability of participating in university education considerably. The probability that a university student has a father who has himself had university education is about twice than for a randomly picked young person. ${ }^{4}$ The introduction of the universities of applied science has contributed to moderating the impact of socioeconomic background on tertiary attainment. ${ }^{5}$

3. The shorter, first bachelor degrees, were delivered by universities in 2004. Almost all students enrol within the new 2-tier system since 2006. In the universities of applied science, the first students graduated with a bachelor degree in 2008.

4. See Bauer and Riphahn (2004), based on data from the Swiss census conducted in 2000.

5. See OFS (2008b). The figures, which are based on students' assessment of parental education, for university students differ considerably from those in Bauer and Riphahn (2004). 


\section{Box 1. The universities of applied science (hautes écoles spécialisées)}

The universities of applied science were introduced in 1996, emanating from institutions offering tertiary vocational education. Their introduction was motivated by the desire to make the upper secondary vocational education pathway more attractive by offering access to academic tertiary education and to help graduates from these institutions obtain internationally recognised degrees. They offer an approach to teaching and research that is more closely oriented to direct applicability. Their research is limited to applied work and they do not offer PhD degrees. More than half of students enter via the vocational education system, obtaining the maturité professionelle. Pupils who graduate from the lycée can also access the universities of applied science but have to gain work experience in order to be allowed to do so. Starting salaries of graduates of universities of applied science are as high as for university graduates but rise less with age. Since their inception graduation rates have expanded well beyond graduation rates achieved in the institutions they originated from. Two private universities of applied science have been accredited. Study duration is a little shorter than at universities, averaging about 3.5 years (prior to the introduction of the bachelor degrees).
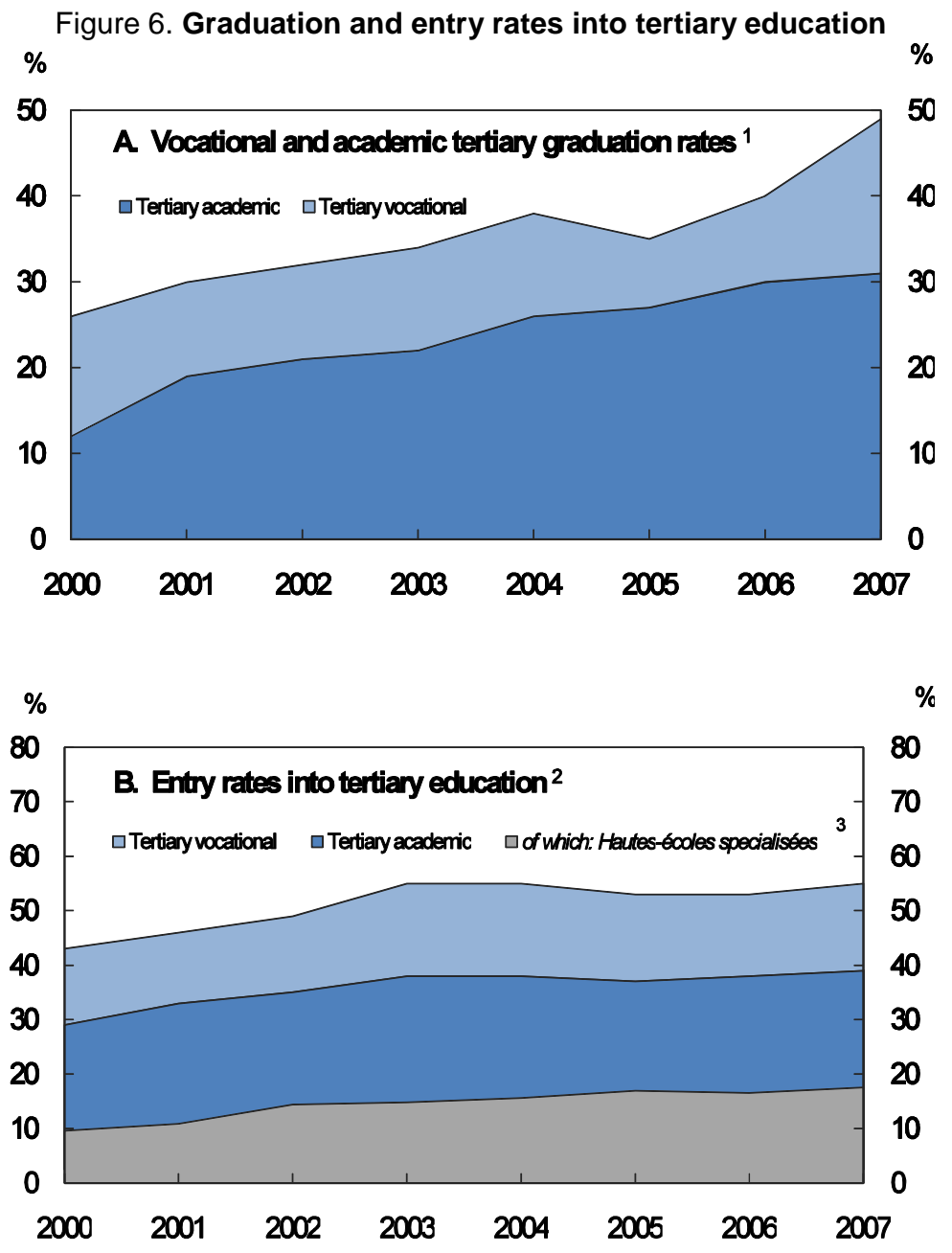

1. Percentage of tertiary graduates to the population at the typical age of graduation.

2. Sum of net entry rates for each year of age.

3. National data on entry rates into hautes-écoles specialisées do not include entrants into master and postgraduate.

Source: OECD, Education at a glance (2009); FSO. 
Private returns to tertiary education in Switzerland are high in comparison to other high-income OECD countries (Figure 7), especially for men. The high private returns are accounted for by relatively large high gross wage premia. ${ }^{6}$ Tertiary attainment contributes little to raising the probability of being in employment, reflecting the high employment rates achieved by graduates from vocational upper secondary education. In recent years, however, employment rates of tertiary graduates have evolved more favourably than those of upper secondary vocational graduates. The returns are particularly high for universities of applied sciences and tertiary vocational degrees (Wolter and Weber, 2005). ${ }^{7}$ Social returns to tertiary academic education - defined here as the sum of private and fiscal net benefits, so include total worker compensation as benefits and take into account public spending on education in the costs - compare less favourably, reflecting the high government spending per graduate (OECD, 2008a).

Figure 7. Estimates of the private internal rates of return to tertiary education ${ }^{1}$
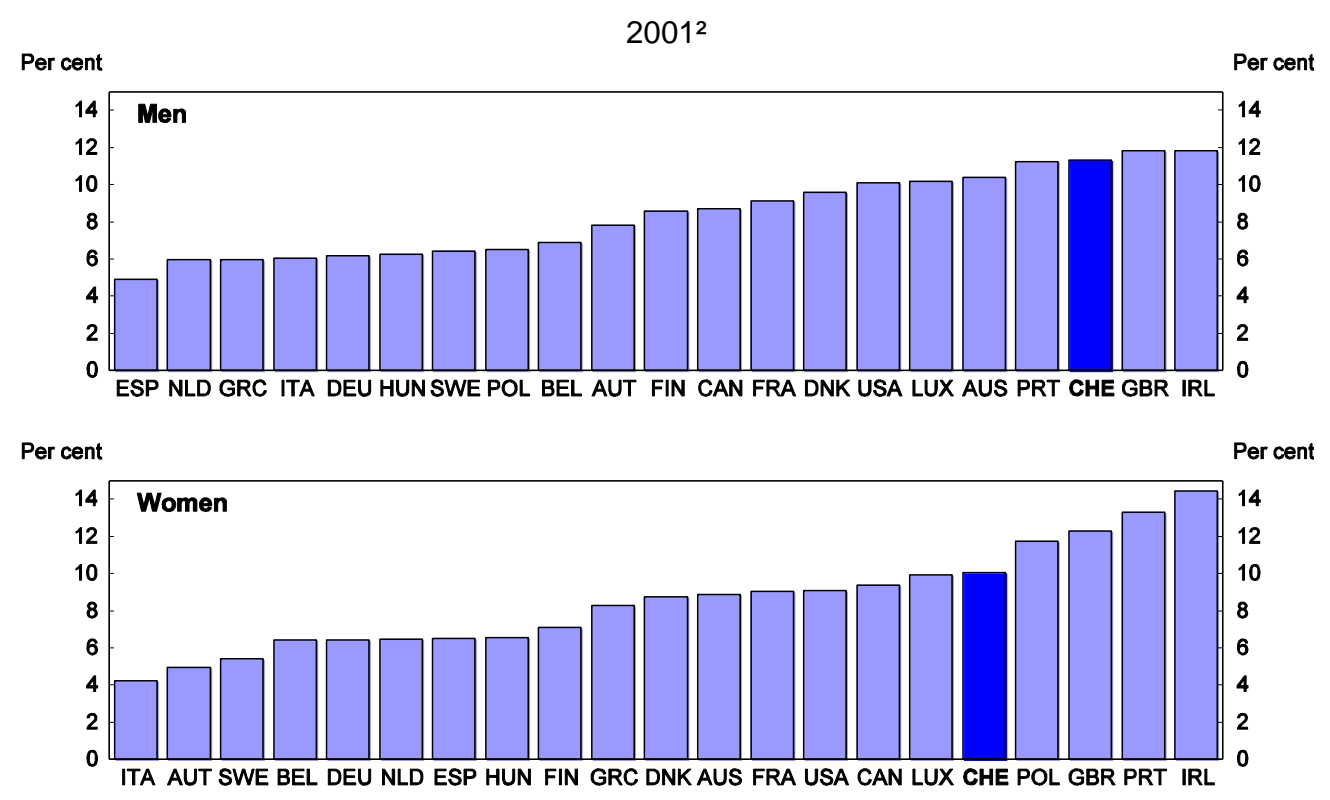

1. Uniform labour productivity growth across countries assumed to be $1.75 \%$ per year.

2. Except Poland and Switzerland: 2000 and Hungary: 1997.

Source: Oliveira Martins J., R.Boarini, H.Strauss, C. de la Maisonneuve and C.Saadi (2007),"The policy determinants of investment in tertiary education", OECD Economics Department Working Paper No 576.

\section{The transition to the labour market of upper secondary and tertiary graduates is excellent}

The Swiss education system is unusually successful in assuring a smooth transition from full-time education to work for most youth. Only $11 \%$ of the population in the age bracket of 20-29 years were neither in education nor in employment in 2006. This is one of the lowest shares among OECD countries and considerably less than the average (Table 2). The successful integration of workers in the labour market from young age, coupled with a low share of workers without formal skills is likely to be an

6. Expressed in earnings per hour controlling for individual characteristics other than education attainment. Estimates are calculated on the basis of average duration of tertiary education in both vocational and academic streams. See Oliveira Martins et al. (2007).

7. To some extent, the estimated returns for the universities of applied science may be overestimated relative to those from universities because most graduates from the former have entered the labour market recently. It appears to be the case, however, that earnings rise less strongly with experience than is the case for university graduates. 
important factor in explaining the modest degree of inequality in the distribution of income in Switzerland. Indeed the Gini coefficient on size-adjusted household income is lower than in a majority of OECD countries, although it is higher than in most small European countries (OECD, 2009a).

Table 2. Trends in the percentage of the youth population in education and not in education

\begin{tabular}{|c|c|c|c|c|c|c|}
\hline & \multicolumn{3}{|c|}{2000} & \multicolumn{3}{|c|}{2006} \\
\hline & \multirow{2}{*}{$\begin{array}{c}\text { In education } \\
\text { Total }\end{array}$} & \multicolumn{2}{|c|}{ Not in education } & \multirow{2}{*}{$\begin{array}{c}\text { In education } \\
\text { Total }\end{array}$} & \multicolumn{2}{|c|}{ Not in education } \\
\hline & & Employed & Not employed & & Employed & Not employed \\
\hline \multicolumn{7}{|c|}{ Switzerland } \\
\hline \multicolumn{7}{|c|}{ Age group: } \\
\hline $\begin{array}{l}15-19 \\
20-24 \\
25-29\end{array}$ & $\begin{array}{l}84.6 \\
37.4 \\
15.0\end{array}$ & $\begin{array}{r}7.5 \\
56.7 \\
73.9\end{array}$ & $\begin{array}{r}7.9 \\
5.9 \\
11.1\end{array}$ & $\begin{array}{l}84.4 \\
36.9 \\
14.7\end{array}$ & $\begin{array}{r}8.0 \\
52.3 \\
73.8\end{array}$ & $\begin{array}{r}7.6 \\
10.8 \\
11.5\end{array}$ \\
\hline \multicolumn{7}{|c|}{ OECD average } \\
\hline \multicolumn{7}{|c|}{ Age group: } \\
\hline $\begin{array}{l}15-19 \\
20-24 \\
25-29\end{array}$ & $\begin{array}{l}80.4 \\
35.4 \\
12.4\end{array}$ & $\begin{array}{l}11.3 \\
47.8 \\
68.6\end{array}$ & $\begin{array}{r}9.2 \\
17.5 \\
19.0\end{array}$ & $\begin{array}{l}85.6 \\
41.4 \\
14.5\end{array}$ & $\begin{array}{r}8.0 \\
44.3 \\
69.1\end{array}$ & $\begin{array}{r}6.5 \\
14.6 \\
16.9\end{array}$ \\
\hline
\end{tabular}

Source: OECD (2008), Education at Glance.

The well-developed upper secondary vocational education system contributes significantly to this favourable result. Indeed, employment prospects immediately after completing full-time education are as good for upper secondary graduates as they are for tertiary graduates. Among a sample of individuals having left full-time education within the preceding 6 to 24 months, graduates of vocational upper secondary degrees have slightly higher unemployment rates than tertiary graduates, but the share of workers in employment and not subject to precarious working conditions is high for all types of graduates (Table 3). However, the share of youth aged 20-24 not in education and not in employment rose somewhat between 2000 and 2006 (two years which are close to cyclical peaks). These individuals are most likely to possess an upper secondary vocational degree. As is the case for unemployment rate trends (see OECD, 2009b), these figures suggest that their labour market entry conditions for this group, while excellent, have deteriorated somewhat in recent years.

Table 3. Employment status after graduation

Per cent of graduates having left full-time education within the preceding 6 to 24 months, 2008

\begin{tabular}{lccrr}
\hline & $\begin{array}{c}\text { Upper secondary } \\
\text { vocational }\end{array}$ & $\begin{array}{c}\text { Tertiary } \\
\text { vocational }\end{array}$ & $\begin{array}{c}\text { Tertiary } \\
\text { academic }\end{array}$ & Average \\
\hline Total & 100.0 & 100.0 & 100.0 & 100.0 \\
Non-precarious work & 74.6 & 82.9 & 74.3 & 76.6 \\
Precarious work $^{1}$ & 14.1 & 13.8 & 19.2 & 15.8 \\
Inactive & 5.4 & $1.0^{2}$ & 3.5 & 3.7 \\
Unemployed & 5.9 & $2.3^{2}$ & $2.9^{2}$ & 3.9 \\
\hline
\end{tabular}

1. In involuntary part-time work, in several simultaneous jobs or in a temporary contract.

2. Less than 50 individuals in sample.

Source: OFS (2008), Labour Force Survey. 
While vocational upper secondary graduates have a highly successful record with regard to the transition to the labour market, their performance compares less favourably over the life cycle. Employment rates of vocational graduates diminish more strongly with age than those of tertiary graduates (Figure 8, which shows employment rates of male workers only, because women's life cycle employment profiles are more strongly affected by child-raising). Earnings profiles for tertiary graduates are considerably steeper than for upper secondary graduates. For example, earnings on average double over the life cycle for university graduates while they rise by $20 \%$ for graduates from vocational upper secondary education (CSRE, 2006). Part of this significant difference in wage growth over the life cycle may reflect higher participation of tertiary graduates in continuous education, perhaps because tertiary studies foster the ability to learn. One possible explanation for this divergent evolution of labour market performance over the life cycle may be that the human capital of vocational graduates depreciates more quickly, as some empirical research suggests for Germany. ${ }^{8}$ This could, perhaps, be explained by the higher degree of specificity of knowledge, which leads to accelerated depreciation of human capital when technological change is rapid, especially in countries close to the technological frontier in many industries (Arvantis et al., 2009, and references therein). However, employment rates also remain relatively high at mature age for tertiary vocational graduates. All in all, these data suggest that continued expansion of tertiary attainment could have a favourable impact on aggregate productivity growth and employment rates in the context of demographic ageing, which will require a lengthening of the life span spent in economic activity and increase the share of workers with long work experience.

Figure 8. Male employment by educational attainment (2006)

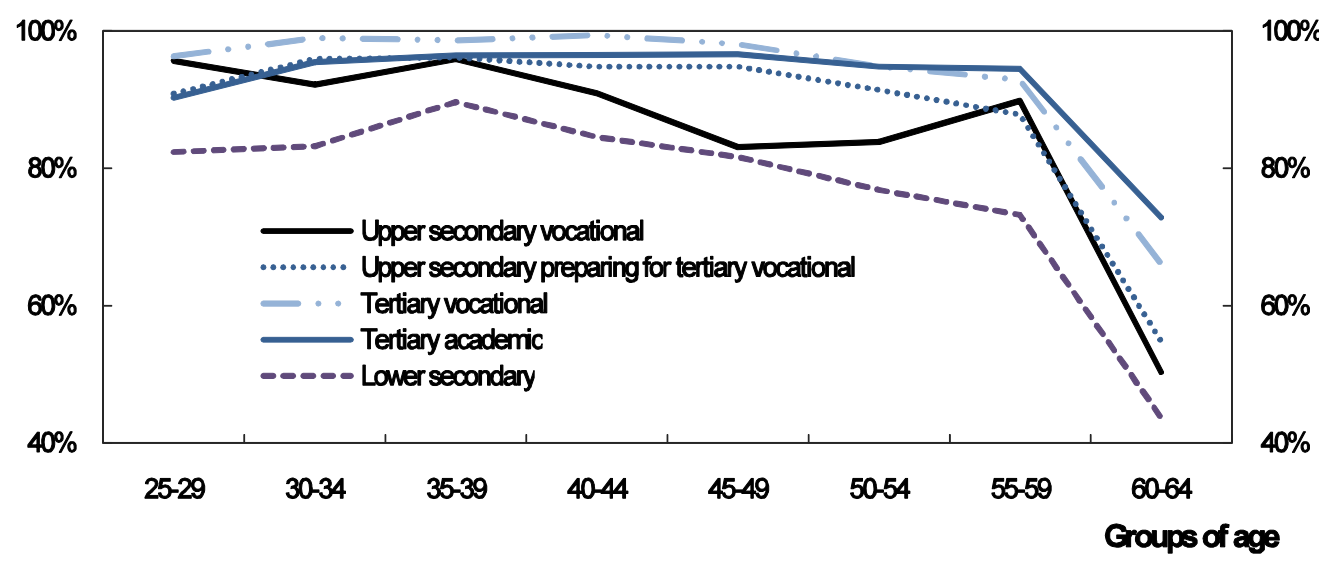

Source: OECD, EAG database.

\section{Growth in demand for tertiary graduates has been strong in recent years}

Trend growth of employment of tertiary graduates has been strong in recent years, considerably stronger than average employment growth. On the supply side, this increase has been fuelled by increased graduation rates at the tertiary level (see above) and by rising immigration of highly qualified workers (OECD, 2007a). The increase in supply of highly-qualified workers has been absorbed relatively easily in the labour market. Unemployment rates for tertiary graduates developed broadly in line with the overall unemployment rate while pay remained stable in real terms between 2002 and 2006 (OFS, 2009b). Employment rates of recent tertiary graduates have risen more strongly than for the population at large between 2003 and 2008 while the share of graduates reporting to be employed in jobs with too low skill requirements diminished. Indeed, the share of employed graduates reporting to be in jobs which do not

8. On the basis of workers' own assessments of the usefulness of the education they have received. See Ludwig and Pfeiffer (2005). 
require a tertiary level degree 4-5 years after graduation fell from almost $20 \%$ in 2002 to around $10 \%$ in 2007 (OFS, 2008). Graduates made their transition to jobs with commensurate skill requirements increasingly quickly, with two thirds of graduates being employed in such a job after 2 months in 2006. Moreover the share of establishments (weighted by their shares in total employment) reporting difficulties in hiring tertiary graduates increased over the past cycle (OFS, 2009). Particularly marked difficulties were reported in hiring tertiary vocational graduates. Hiring bottlenecks for highly-qualified workers appeared to be particularly binding in financial intermediation, transport and communication as well as information technology.

Meeting the additional demand through higher supply could have a favourable impact on productivity growth. The evidence presented in Arvanitis et al (2009) ${ }^{9}$ suggests that, within any industry, firms with a relatively high share of workers with tertiary education have higher productivity levels than other firms, holding the share of workers with upper secondary vocational attainment and other determinants of firm level productivity constant. Conversely, firms with a relatively high share of upper secondary vocational graduates do not seem to have robustly higher productivity, holding the share of workers with tertiary attainment constant. A positive contribution of intermediate vocational skills is discernible if attention is limited to firms with relatively low productivity. Among highest-productivity firms, the correlation between the share of workers with intermediate vocational skills and productivity turns negative.

The results of this paper must however be interpreted as being descriptive rather than as reflecting a causal relationship because the data do not permit controlling for unobserved heterogeneity among firms. However, the supply of tertiary-level skills in Switzerland has grown more slowly than in other OECD countries and there are some signs that the labour market could absorb a larger increase of tertiary-skilled workers. Moreover, the share of tertiary graduates among recent immigrants has been larger than among the Swiss population of working age, in part reflecting policies encouraging the immigration of highly skilled workers (see the 2007 Economic Survey), and the increase in the supply of tertiary skills in recent years has been absorbed well, with a high match quality, while the share of businesses noting shortages in recruiting tertiary graduates has risen, as noted above. Taken together, this evidence suggests that a further increase of the supply of highly skilled workers could foster the expansion of the most productive businesses in Switzerland. International evidence also indicates a strong link between cognitive skills, as measured in adult literacy scores, and individual earnings, with a particularly marked effect in Switzerland (Hanushek and Woessmann, 2008, and references therein). Moreover, there appears to be a causal relationship between cognitive skill levels on the one hand and aggregate economic growth on the other hand, including when the share of high performers is considered (although this evidence relies on test scores obtained at secondary level).

\section{Reforms to raise education outcomes}

\section{Public spending is relatively low on education of very young children}

Education spending as a share of GDP in Switzerland is close to the average in the OECD (around 6\%). However, spending per pupil relative to GDP per capita is high. This is explained to a considerable extent by relatively low participation rates in early childhood and tertiary education. Spending per student is higher in the later stages of the education career (especially in upper secondary and tertiary academic education) in most OECD countries. In Switzerland, this tendency is considerably more marked than in other OECD countries. Spending per pupil is low on pre-primary childhood education (Figures 9 and 10). Fees are often high for childcare facilities for children below the age of 4 , entailing low participation (see further below).

9. OECD (2009b) contains a summary of the findings of the research of this paper. 
Figure 9. Spending per student and GDP per capita ${ }^{1}$
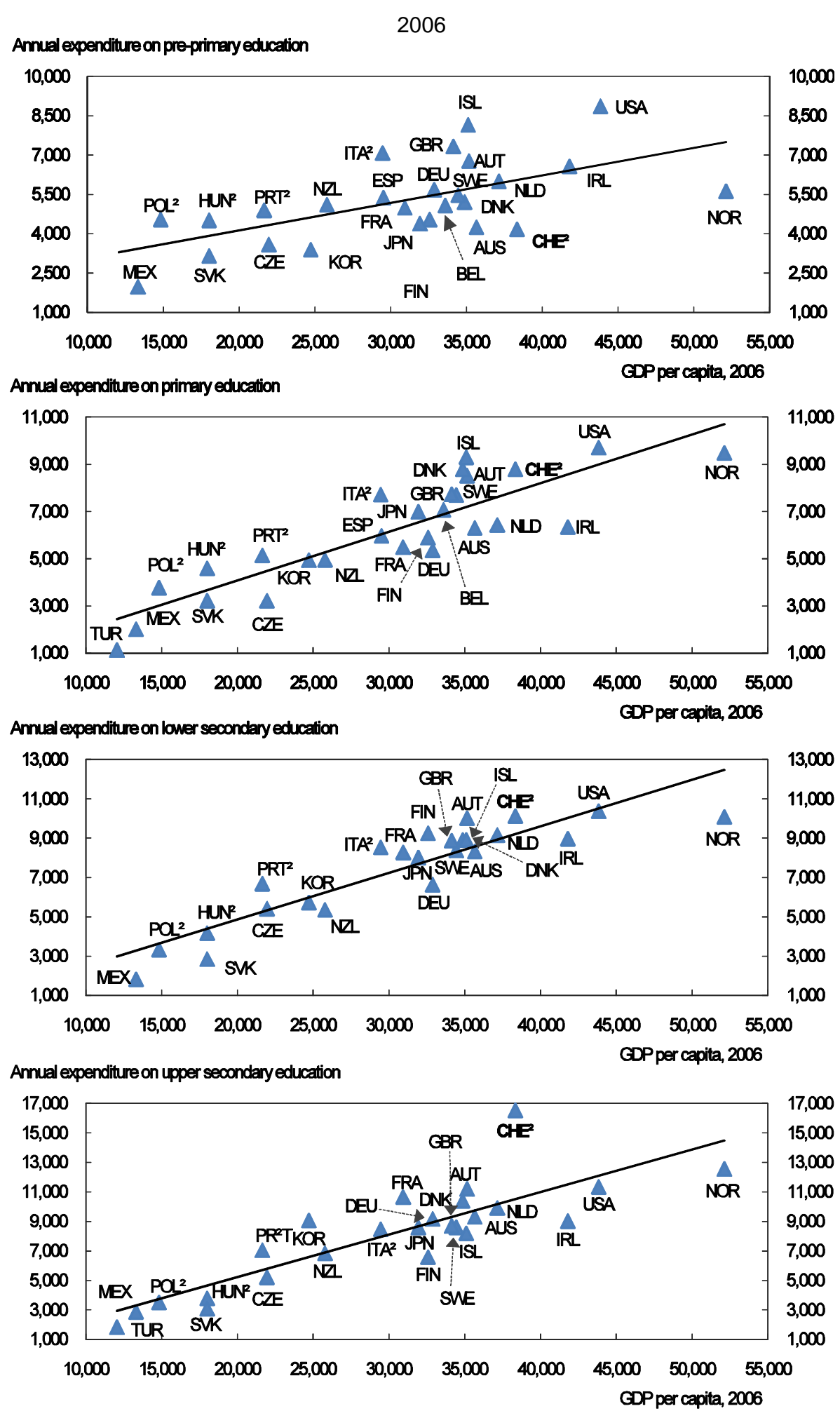

1. In equivalent USD converted using PPPs for GDP, by level of education, based on full-time equivalents.

2. Public institutions only.

Source: OECD, Education at a Glance (2009). 
Figure 10. Cumulative spending per student in tertiary education, 2006

Expenditure for all services over the average duration of tertiary studies In USD converted with PPPs, by type of programme

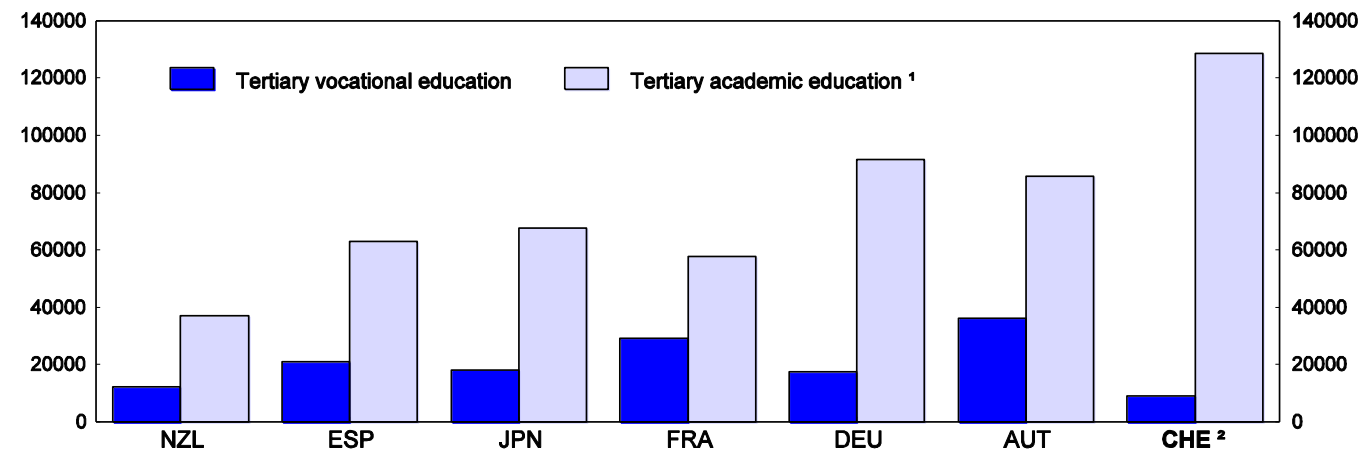

1. Includes expenditure on advanced research programmes.

2. Public institutions only.

Source: OECD, Education at a glance (2009).

As in a majority of OECD countries, most spending is public, including in tertiary academic education. An important exception, in Switzerland, is vocational upper secondary education, for which firms make significant training outlays for on-the-job training. Roughly half of the cost of vocational education is born by employers (Höckel et al. 2009). Since apprenticeships are profitable for firms on average over the whole duration of the apprenticeship (see e.g. Wolter, 2008), these private costs are largely ultimately born by the trainees through time spent working with wages which are below the marginal product. ${ }^{10}$ The time trainees need to work to fund the cost of their training might constrain the time they can devote to education. This circumstance could perhaps raise the question whether they spend an amount of time on education that is optimal with respect to its life-time net benefits, including in terms of improved life time employment prospects. As noted above, most education is imparted at the workplace. The fraction of time spent in school per week varies, typically ranging 1-2 days per week (Höckel et al.). According to an analysis of the Adult Literacy Survey, which tested reading, mathematics and problem solving skills of the adult population, the average score reached by upper secondary vocational degree holders was 41 points. Individuals with compulsory school reached 33 points on average (see Falter et al., 2007) and holders of maturité degrees (including maturité professionelle) 61 points. Some of these differences are likely to be accounted for by selection effects. A slightly larger share of time spent in school education might induce more graduates to obtain the maturite professionelle, giving access to the universities of applied science, whose degrees appear to offer relatively high returns, although policy makers would also need to avoid raising the number of drop-outs. Public spending per student on upper secondary general education, where there is no significant private contribution to funding, is about $25 \%$ higher than in compulsory education (OFS, 2009a) and considerably higher than in vocational upper secondary education. Government spending per student is also considerably lower in tertiary vocational than in tertiary academic education.

It was argued in OECD (2007c) that it is questionable whether higher public spending per student in later education phases is an appropriate setting of priorities for efficiency and equity reasons: First, there is evidence that the effectiveness of education imparted at any given level depends heavily on how effective education has been in previous stages (Heckman and Masterov, 2007), suggesting that the marginal benefit

10. This is consistent with the prediction from human capital theory that the cost of obtaining skills which are useful across many firms must be borne by the trainee. 
of public spending in the early stages is high, especially in Switzerland where participation in pre-primary education and childcare is still relatively low. While the link between the level of resources and education outcomes is often weak, there is evidence that, for example, class size has a more important impact for very young pupils from disadvantaged backgrounds (see e.g. Piketty and Valdenaire, 2006, for evidence on France). Second, most students pursuing long education careers tend to have family backgrounds which over-represent favourable socio-economic backgrounds. Public spending favouring the later stages of an education career thus tends to be regressive. This point is particularly marked in Switzerland, where vocational pathways receive less public funding than non-vocational ones. Third, early education has particularly pronounced public and merit goods characteristics: education failures at a young age are likely to entail large costs for the society at large (such as through welfare spending) and parents whose children are likely to benefit the most may not be able to fully assess the benefits.

In view of the private benefits to higher education there is a case for allowing private funding to play a more significant role in tertiary university education, without putting access of students from low socioeconomic backgrounds to higher education at risk. Resources for education spending in early childhood education could also be mobilised from savings in social spending entitlement programmes, notably health and disability (OECD, 2007a).

While the federal government makes a significant contribution to university funding, public spending on primary and secondary education is mostly funded by the cantons. The municipalities have significant responsibilities in the funding of childcare as well as early childhood and, to a lesser extent, primary education. Allocating significant funding responsibilities to municipalities generates geographical spill-overs which may contribute to under-provision especially where attendance is not compulsory. The benefits in terms of subsequent better education and labour market outcomes are often not reaped by supplying municipalities as a result of geographical mobility. Moreover, since a significant part of the benefits does not accrue to the individual but to all tax payers nationwide, through higher tax revenue and lower welfare spending, and meritorial characteristics, as argued above, parental voters are unlikely internalise those benefits in voting decisions. The positive impact of more generous provision of preprimary education on female labour supply might also be subject to externalities, as parents may choose to place their children in a facility outside their municipality of residence (OECD, 2006a).

\section{Improving the contribution of pre-primary education to outcomes}

A large body of empirical work has established that fundamental cognitive and non-cognitive abilities are produced in the early years of childhood, long before children are five years old. Children from disadvantaged families receive much less cognitive and emotional stimulation than other children, retarding development (Heckman and Masterov, 2007). For these children, attendance of childcare and pre-school education facilities is effective in avoiding learning difficulties later on (e.g. OECD, 2006d). There is substantial evidence showing that schooling at a very young age raises educational opportunities at later stages, especially for those with fairly poorly educated parents (Cunha et al., 2006). It also raises the share of pupils who are able to pursue education at the tertiary level (Caneiro and Heckman, 2003). A considerable body of evidence from several OECD countries almost unanimously points to the success of measures to address weaknesses in child development very early on, including, for example, household visitation programmes in New Zealand and the United States (OECD, 2006d).

\section{The supply of childcare facilities remains scarce}

While no nation-wide administrative statistics exist on the participation of children below the age of 4, Labour Force Survey data show that less than a quarter of couples whose youngest child is less than 6 years old make use of some childcare (formal and informal) for more than one day per week. A third of these families make use of a formal collective structure. Immigrant children are less likely to attend childcare facilities, according to a study of attendance in three Swiss towns (OECD, 2007b and references 
therein). A quarter of facilities do not offer subsidized places for low-income families, and, among those which do, little more than a half of the places are subsidized (BKFF, 2008). Subsidized facilities are subject to waiting lists. Existing places are often not made available at times and for age groups for which demand is particularly high (EKM, 2009).

To address the lack of childcare facilities resulting from deficiencies in funding, the government introduced a co-funding scheme from 2003, covering up to $30 \%$ of the initial investment and operating costs for up to 3 years. To receive the subsidy the provider must be able to fund the service over a period of six years and ensure minimum opening hours. The scheme is scheduled to end in 2011, although the government has submitted an extension for public consultation, as well as a proposal to give the federal government powers to develop new forms of financial support for childcare facilities. The scheme has been effective in raising the number of available places, which increased by $40 \%$ since it was put in place, albeit from a very low base. The amount of funds awarded depends on the number of places created and on the number of new occupied places. Since the introduction of the scheme in 2003, CHF 127 million have been committed (less than $0.1 \%$ of yearly GDP).

While the scheme may have succeeded in maximising additional childcare places for a given volume of subsidies, the design of the programme suffers from shortcomings. The facilities are not subject to federal quality standards or federal evaluation of quality standards but instead require providers to meet cantonal requirements, which vary. A few cantons have adopted regulations to ensure minimum quality standards for inputs (such as the number of children per staff, conditions of physical infrastructure). Among these cantons, fewer than one half have included pedagogical objectives (Stadelmann-Steffen and Stamm, 2009). The federal scheme may generate incentives for cantons to lower quality requirements, so as to be able to expand the supply of new places more quickly and to be able to limit their cofunding share to the minimum of $70 \%$. Although the scheme respects the principle of allowing the subsidy "to follow the child" it fails to direct funds to those institutions which meet parental demands best, because it distorts competition between established and new facilities and does not direct priority funding to those children who are likely to enjoy the largest educational benefits. Moreover, the subsidies are not subject to conditions concerning the fees charged to parents.

A scheme of vouchers, linked to a nation-wide accreditation system, could ensure that supply adjusts better to parental demand and that financial support is directed to children who would benefit the most from the beneficial impact of childcare on their subsequent education outcomes. Such vouchers could cover a significant share of the average cost of provision of a place in a childcare facility and could be targeted, in the first instance, at households whose children have special education needs, notably lowincome households and households in which the children do not speak the local language. Accreditation criteria should include standards with respect to educational targets. To support the provision of childcare facilities, a voucher scheme should be introduced and linked to a system of accreditation and nation-wide quality standards. Subsidies for childcare provision also have a significant impact on female labour supply, in part by creating a denser network of facilities, thereby reducing commuting costs, and these effects may well be particularly marked in Switzerland, where many women work part-time. The federal government has presented a draft ordinance for public consultation which would introduce such minimum quality standards as well as a nation-wide agency, to be created by the cantons jointly, which would be responsible for the accreditation and supervision of childcare facilities. It has also funded pilot projects for voucher schemes. These are welcome steps forward.

Parliament has adopted new legislation which reduces the income tax payments of families with children with an estimated budgetary $\operatorname{cost} 0.1 \%$ of GDP. The legislation includes a new allowance for children, which is deducted from the tax payment (CHF 250 per child), as well as the deductibility of childcare costs from taxable income up to a limit of CHF 10000 for children up to the age of 14 years. The former measure is however likely to reduce labour supply, while the latter measure is not suited to target 
childcare provision with educational benefits, especially among parents with low socio-economic background, who are likely to face low marginal income tax rates. Consideration should be given to redirect the resources devoted to the new child and childcare allowances to a voucher scheme for childcare as described above.

\section{The planned lowering of compulsory education to the age of 4 marks progress}

The Swiss system of early childhood education and childcare (ECEC) distinguishes early childhood education for children from age 4 onwards (écoles enfantines) and childcare facilities, which are also provided for younger children. Attendance in early childhood education has increased from $35 \%$ to $86 \%$ of children aged 4 between 2004 and 2008. A new cantonal agreement - the HarmoS concordat - will lower the start of compulsory free schooling from 6 to 4 years nation-wide if approved by all cantons (Box 2). Indeed, in view of the significant benefits of early childhood education and the difficulties parents with low educational attainment may have in assessing such benefits, compulsory pre-school can make a significant contribution to raise education outcomes for children, especially from socially disadvantaged backgrounds. This argument may carry particular weight in the case of Switzerland, where compulsory school finishes already at age 15 , and some students in upper secondary education, notably those pursuing short degrees in the dual apprenticeship system, receive little general education beyond that age.

Cantons which have agreed to the HarmoS concordat will have considerable leeway in how they will implement compulsory schooling from the age of 4 onwards. While high-standard qualification requirements on pedagogical staff are set across cantons, ${ }^{11}$ attendance times and teaching input will remain at the discretion of individual cantonal governments. At present many cantons provide attendance of less than half a day, which also limits the capacity of parents, notably mothers, to work full time if they wish to do so. Moreover, many cantons have introduced objectives for the educational phase before the age of 6 . However, the HarmoS concordat does not foresee such standards. The cantons are encouraged to accelerate in the introduction of compulsory schooling from the age of 4 . They should set common educational objectives, evaluate education outcomes and offer full-day attendance.

Very young children with education needs which are particularly difficult for parents to meet - including highly talented children, children of parents with low socio-economic background and children whose parents do not speak the local language - can benefit particularly strongly from early childhood education. In Switzerland, these special needs are, in most cases, not taken into account. In particular, early childhood education facilities are not placed in a position to help compensate the learning needs of children with parents from poor socio-economic backgrounds (Stadelmann-Steffen and Stamm, 2009). In Germany, some states have moved to test children's local language abilities 2 years before the beginning of primary school and to enrol young children in special support programmes if weaknesses emerge. In recognition of the higher cost of such programmes, pre-schools receive higher capitation subsidies for immigrant children (OECD, 2008b). The capacity of early childhood education and childcare facilities to support children with specific education needs should be strengthened.

\section{Improving efficiency in compulsory education}

While cantonal governments are autonomous with regard to their policy settings for compulsory education, they have agreed on common basic structural elements (Box 2). Thus, in all cantons compulsory schooling currently begins at age 6 and lasts until age 15. Primary school in most cantons covers the first 6 years of schooling, although in 2 cantons it lasts for 5 years and in some for 7 years (including an orientation phase). In most cantons selection of pupils into different tracks at the end of primary education is widespread. Cantons belonging to the same language community set common rules on the content of teaching in core subjects. However, the sequence and timing of the teaching of non-native and foreign

11. These stipulate a university-level degree combining academic education and practical training. 
languages differs considerably, even among cantons with the same main language, which has generated some barriers to intercantonal mobility of families with children.

The cantons have therefore decided to reinforce common structures in the HarmoS concordat, following a recent constitutional amendment which provides the cantons with a mandate to do so (Box 2, see also OECD, 2007a, for the main provisions of the HarmoS concordat). A common core catalogue of subjects will be defined and basic course contents will be more closely harmonised.

\section{Box 2. Assignment of responsibilities across levels of government}

Municipalities are, together with the cantons, in charge of funding pre-primary education and childcare as well as part of the expenditure of primary education, notably for physical infrastructure and teaching materials. They also run primary and lower secondary schools.

Cantons regulate all compulsory education as well as upper secondary education in the academic stream, although all final upper secondary degree requirements are set in cooperation with the Confederation. They provide all public funding for lower secondary and most of upper secondary education, including in the vocational track. The cantons have responsibility for cantonal universities and the Universities of Applied Science (Hautes Écoles Spécialisées). Cantons also contribute most of the funding for education services in these institutions and are in charge of setting up grants and loan schemes for students, which they mostly fund themselves, with a small contribution from the Confederation.

The cantons coordinate their education policies in the Swiss Conference of Cantonal Ministers of Education, which comprises the members of cantonal governments in charge of education and oversees the implementation of agreements across cantons. The foundation for this cooperation was laid in the school concordat from 1970, in which cantons agreed on for example, mutual recognition of degrees, common features in curricula, common requirements on teacher qualification. It also sets common basic features in compulsory schooling, including the age thresholds of compulsory schooling, An additional concordat (HarmoS) has been approved by some cantons (see below).

The confederation regulates vocational education at the secondary and tertiary level, although most public funding is provided by the cantons. It also sets the framework conditions for academic tertiary education and is responsible for the two Federal Institutes of Technology (écoles polytechniques fédérales), for which it provides all public funding. It also regulates the Universities of Applied Science (hautes écoles specialisées), although the cantons are responsible for operating them. The confederation also provides between 20 and $40 \%$ of the funding of the cantonal universities (universities cantonales; OFS 2009b) and one third of the funding of the universities of applied science.

A recent constitutional amendment, approved in a referendum in 2006, requires the cantons and the confederation to harmonize key aspects of the education system nationally, in particular with respect to the entry age and duration of compulsory education, the setting of education objectives, and access conditions. It also prescribes that confederation and cantons co-ordinate their policies towards institutions offering tertiary academic education (see Box 3). It empowers the federal government level to harmonize these key elements on its own if the cantons do not reach agreement. In June 2007 the Swiss Conference of Cantonal Ministers of Education agreed on the HarmoS Concordat to comply with this requirement. If implemented in all cantons, it will introduce common standards for education outcomes in compulsory education and lower the beginning of compulsory education from age 6 to 4 in all cantons. It will offer continuous schooling hours and to offer day-care for pupils so as to better reconcile attendance with working hours of parents and reduce differences in curricula within each language community so as to reduce geographical barriers to mobility for families with children. The HarmoS concordat has been in force since 1 August 2009 for the 11 (out of 26) cantons that have agreed to it. It has been rejected in 7 cantons, among which by popular vote in 6 cantons. The cantons in which the concordat is applied have 6 years to fully implement its provisions. 
School autonomy is strong in some respects but accountability is weak

Almost all schools in lower secondary education appear to be autonomous in decisions related to selection and the dismissal of teachers (OECD, 2007a). This also applies to upper secondary schools, of which two thirds hire teachers themselves. Schools thus have considerable influence on personnel decisions, as teachers, like all public sector employees in Switzerland, do not have special job protection rules. Most schools can also take decisions on the use of their budget independently. However, they have little autonomy in decisions concerning teaching material and course content. In many cases, these decisions are mostly taken by cantonal governments alone (Figure 11).

\section{Figure 11. Involvement of schools in decision making ${ }^{1}$}

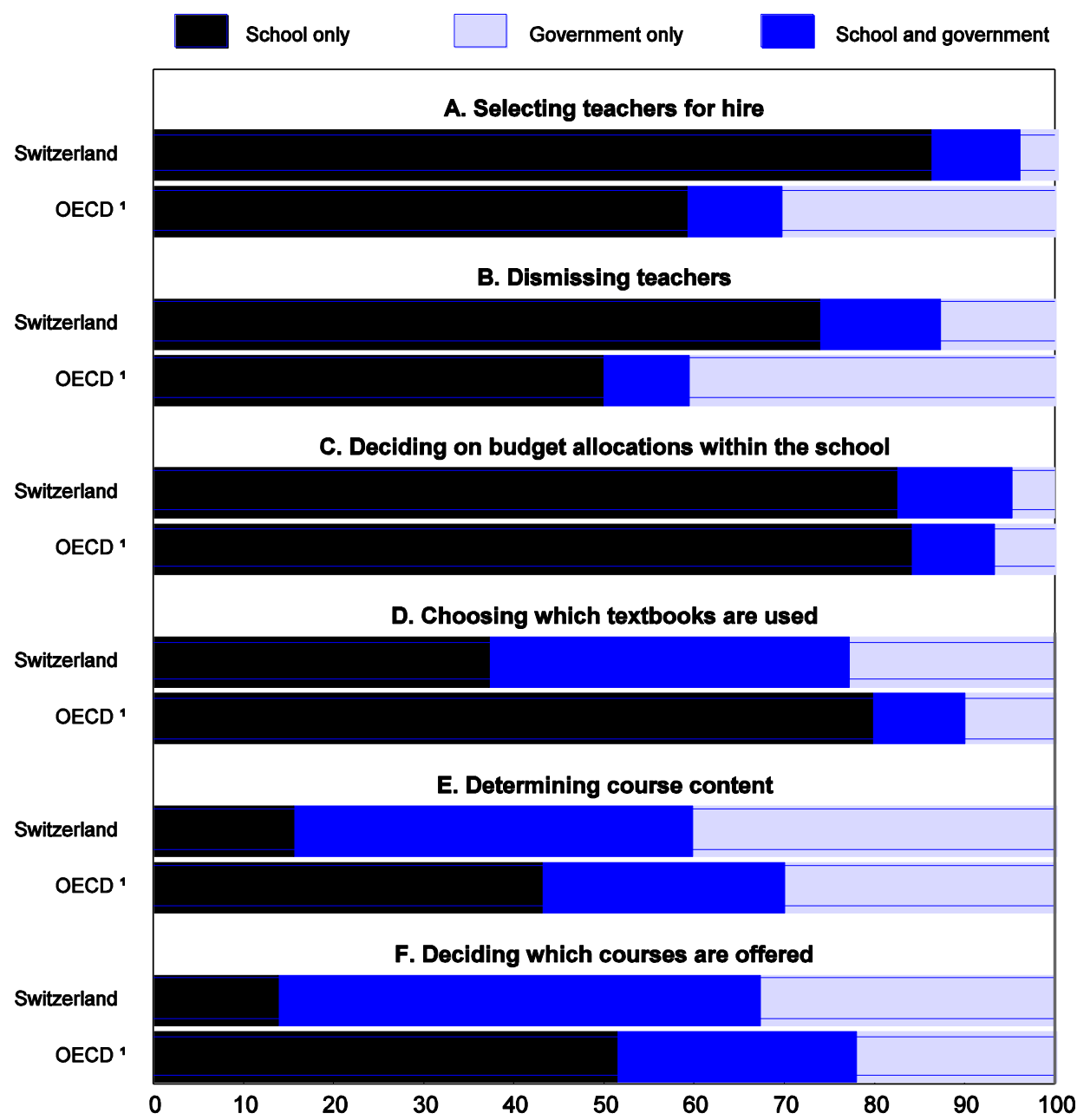

1. Results based on reports from school principals and reported proportionate to the number of 15 -year-olds enrolled in the school.

2. Simple average.

Source: OECD, Pisa 2006: Data, Volume 2. 
Empirical evidence suggests that autonomy of schools in some respects can raise school performance, but only if combined with accountability of schools for outcomes. Otherwise there is a risk that autonomy is not used to the best advantage of raising outcomes. Indeed, school autonomy with regard to teacher salaries has been estimated to increase maths outcomes somewhat, ${ }^{12}$ if accountability mechanisms, such as external final exams, are in place (Wößmann, 2005a). Conversely, external final exams can be counterproductive if schools do not have autonomy with regard to teaching contents. With external final exams, the PISA score in maths is estimated to improve by 19 points if schools have autonomy over teaching content, whereas they deteriorate by 12 points as a result of such autonomy if no external final exams are set. School autonomy in procedural matters, for example in the choice of books, the purchase of teaching materials, the hiring of teachers and the use of the budget, was also estimated to have a positive impact on schooling outcomes. According to Wößmann, externally set final exams boost outcomes by as much as what pupils learn in one school year; and the effect appears to be greater if there are also regular standardised tests to monitor pupil performance in the course of their school careers. ${ }^{13}$ Other methods of enhancing school accountability used across OECD countries include the publishing and qualitative monitoring of school results. Finland - which has achieved high PISA scores in recent years - has made use of a randomised inspection service. Whichever method is employed, the collection of information on results needs to be followed up by analysis to allow recommendations to be drawn for school practices.

While many cantons have made efforts to introduce mechanisms of accountability, scope for improvement is large. Most cantons have occasionally evaluated education outcomes for selected competencies. However, with the exception of the canton of Geneva, they have not been conducted as recurrent exercises over time (CSRE, 2006). Moreover, these programmes have not generally allowed comparisons across cantons. No nationwide evaluation of reading competencies in primary school has been conducted since 1991. Hence the opportunity to determine best practice among cantonal policies is foregone. Indeed, differences in resource utilisation and policies are considerable across cantons. For example, while the overall number of hours taught per year in primary school is slightly above the average of OECD countries (CSRE, 2006), it varies considerably across cantons. The number of hours of instruction is one of the few inputs that have robust explanatory power in accounting for cross country differences in educational outcomes (OECD 2006a) and substantial effects on performance have also been estimated for Switzerland (OFS/CDIP, 2009). Differences across cantons also exist with respect to the method of school evaluation, the distribution of hours taught across subjects, work requirements on teachers and curricula. Significant differences are also apparent in spending per pupil in primary education (Figure 12). The data suggest that there may be a risk that spending tends to be lower among cantons and municipalities with a high share of low-income households. At the same time, it is in the municipalities with many low-income households where a high level of resources in the early phases of education may be particularly effective in raising outcomes.

12. In PISA by 4 points and in TIMSS (Trends in International Mathematics and Science Study) by 20 points (relative to an international average of 500 points in both studies).

13. With standardised tests, PISA maths results are estimated to improve by 28 points as a result of the introduction of centralised exams. When standardised tests are absent the gain is only estimated to be 9 points (Wößmann, 2005a). Moreover, if external exams are absent, regular standardised tests were found to be counterproductive. 
Figure 12. Expenditure per pupil on primary education and GDP per capita across cantons 2005, CHF

\section{Expenditure per pupil}

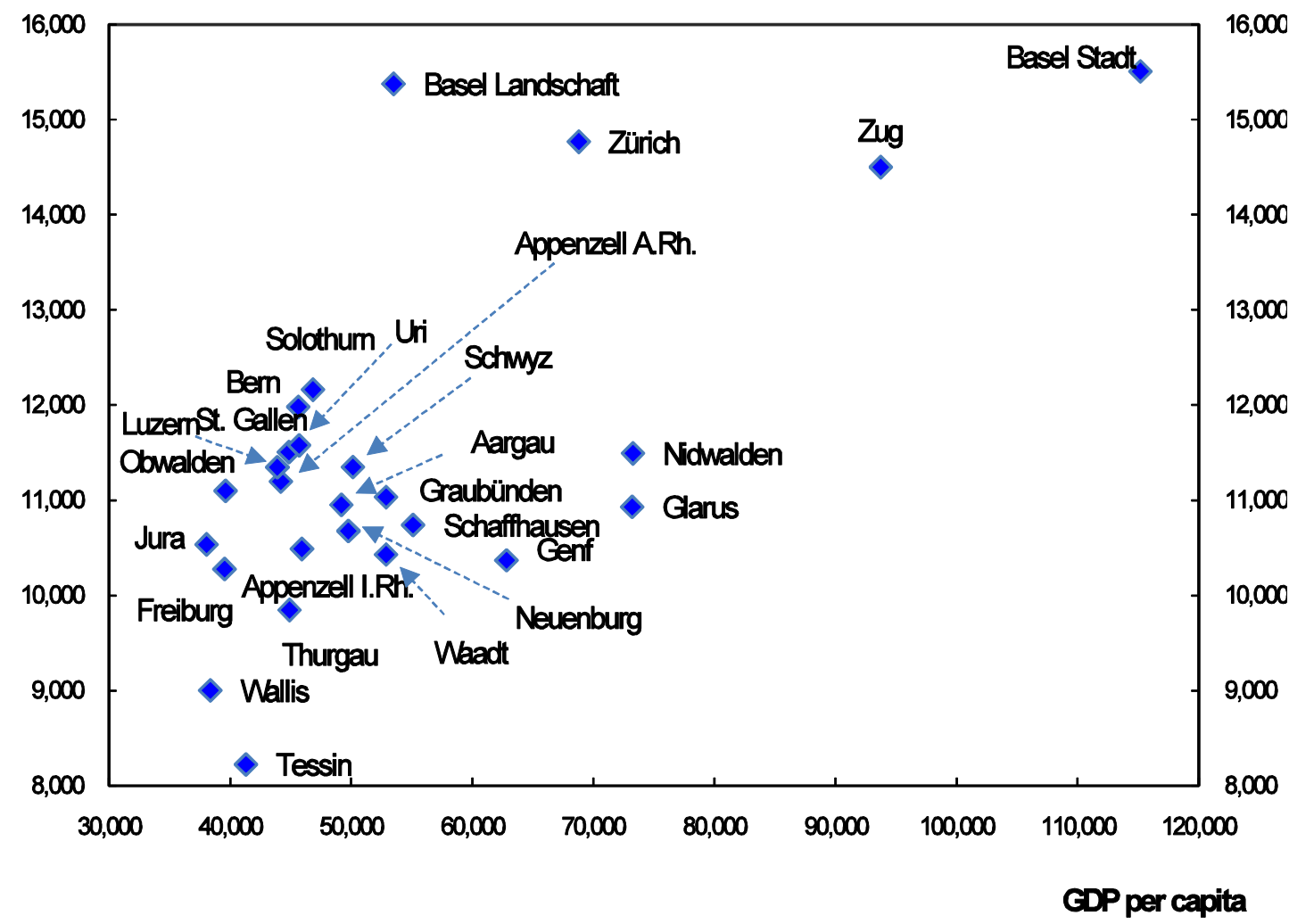

Source: Swiss Federal Statistical Office, 2008.

The cantons which have approved the HarmoS concordat will share education standards for the second, sixth, and $9^{\text {th }}$ (final) year of schooling in core subjects. These standards are being prepared by the Swiss Conference of Cantonal Ministers of Education, on the basis of recommendations from a commission of scientific experts. Implementation of this programme is important, so as to be able to identify best practice among cantonal education policies. The impact of differences in education policy, spending and resources across cantons should be investigated regularly and the results published.

The evaluations planned in the HarmoS concordat cover representative samples of cantonal schools and therefore cannot be used to hold individual schools accountable for their performance. Cantonal evaluations have also, in almost all cases, been sample-based. School inspection services are not geared towards the evaluation of education outcomes. A few cantons have moved towards the definition of competencies, which help set objectives more clearly while giving schools more room to determine themselves how to attain them and have recently introduced central exit exams at the end of compulsory school very recently. Few schools report that achievement data are tracked by authorities or used for the allocation of resources inside schools (OECD, 2007a). Accountability of schools for education outcomes should be strengthened. To this end, external testing should be conducted at regular intervals over time and over the school career at all schools, and the results should be benchmarked against the newly defined competency objectives. In view of the empirical evidence in favour of the complementarities between external exit exams and repeated external evaluation throughout the school career, such regular external testing would help ensure that the new external exit exams at the end of compulsory school, introduced in some cantons, would have a beneficial impact on outcomes. 
A minority of cantons foresee the possibility of teaching evaluation playing a role in pay and career advancement of school managers and teachers. The evidence on the effectiveness of performance-related elements in teacher career is mixed. ${ }^{14}$ However career incentives for head teachers can help hold schools accountable more effectively.

School management teams with clearly defined responsibilities and powers to set strategic objectives and improving the school's education practice can make it easier to hold schools accountable for performance. Training of school managers for these tasks and significant premia of school managers' pay over teachers' pay play an important role to ensure competent school management (Pont et al., 2008). In Switzerland head teachers are little involved in assessing teaching practice in their school. ${ }^{15}$ No nationwide requirements on qualification of school managers exist, although they are in process of elaboration. While teachers in Switzerland are generally well paid, pay premia for school managers are often small, ${ }^{16}$ giving rise to difficulties in filling vacant head-teacher positions. Moreover, few schools have any full-time head teacher and some have no head teacher at all, although in some cases this reflects small school size. Staff devoted to school management should be introduced more widely. Their responsibilities and powers should include setting of objectives, developing plans to improve practice as well as evaluate and help develop teaching skills. Head teachers should be required to acquire school management skills in all cantons. A cantonal agreement to set a common standard for such skills is in preparation.

\section{Selection lacks effectiveness in assigning pupils to tracks according to ability in lower secondary education}

Most cantons' school systems select pupils into two or three types of lower secondary school (schools with basic, medium and extended demands) at the age of between 11 and 13 years. 2 cantons offer comprehensive schooling only, although streaming of pupils for core subjects within schools is also practiced in these. Admission to lower secondary schools with extended demands is based on recommendations from teachers towards the end of primary school. In several cantons pupils have to pass an exam if they do not receive a recommendation from the teachers to be admitted to a school with extended demands. In many cases parents appear to take the final decision (OECD, 2007b). About 60\% of pupils attend schools with extended demands, whereas $30 \%$ attend schools with basic demands. These shares have remained stable over the past 10 years.

The probability of children at a given performance level having been placed in a lower secondary school with extensive demands depends heavily on socio-economic background, gender and immigration status. For pupils with PISA scores close to the average this probability is about $50 \%$ higher for girls with a middle or high socio-economic background than for girls with low socio-economic background, and is about $2 \frac{1}{2}$ times higher for a native boy with high socio-economic background than for an immigrant boy with similar socio-economic status (CSRE, 2006 and references therein). ${ }^{17}$ The weak correlation of study programme and PISA score also suggests that, nation-wide, there is significant overlap in the PISA scores found across different school types.

Differences in cantonal selection criteria appear to contribute to the difficulties in assigning pupils with highest competency levels to schools with higher demands consistently nation-wide. Indeed, across

14. Hanushek and Rivkin (2006), argue in favour, but OECD (2005) provides a sceptical review.

15. Only $40 \%$ of Swiss head teachers report having surveyed in-class work of teachers in maths over the course of a year, less than in most OECD countries, according to 2003 PISA survey data. (Pont et al, 2008).

16. For example, in the canton of St. Gall, the starting salary of a head teacher can at most be $20 \%$ above a teacher's salary and head teacher positions are not generally full-time posts. According to the Weisungen zur Schulleitung vom 1. September 2004 Erziehungsdepartement St. Gallen.

17. According to data from 2001. 
cantons the average PISA scores of schools with basic or medium requirements overlap with the average scores of schools with extended requirements in other cantons (économie suisse, 2008).

\section{Early tracking strengthens the dependence of learning outcomes on socio-economic background...}

Cross-country evidence suggests that comprehensive school systems generate PISA outcomes which are considerably less correlated to socio-economic background than tracked school systems (see, e.g. OECD, 2007b, 2008b and the references therein) and a few countries which have delayed or abolished tracking have diminished this correlation while improving average performance. This has been the result of the abolition of tracking in Sweden in the 1950s and postponement of tracking by one year in Poland in 2002 (OECD, 2007b). In Switzerland, too, there is evidence that the correlation of education outcomes on socio-economic background increases once the pupils have been placed in different tracks (Vellacott and Wolter, 2005). This is, perhaps, consistent with micro-evidence on peer effects, which suggests that the presence of academically strong pupils reinforces education outcomes of weak pupils, while adverse effects of weak students on strong students may perhaps be smaller or absent. ${ }^{18}$

Peer effects are particularly important for learning the local language and therefore contribute significantly to the success of integrating immigrants' offspring in formal education. Reading skills of non-native speaking pupils are considerably better if their share in the school class is relatively small (whereas the reading skills of native speakers of the local language does not appear much affected, see Vellacott and Wolter, 2005, and Nusche, 2009). 60\% of pupils in lower secondary schools with lower requirements have a cultural background ${ }^{19}$ that differs from the local one, whereas the share is less than $20 \%$ in schools with higher requirements. The selective school system therefore appears to generate risks for the progression of immigrant children.

A relatively high share of pupils with learning difficulties are separated from mainstream teaching and placed in classes or schools for children with learning difficulties or disabilities. This share appears to be high in international comparison although some reduction has occurred in recent years (according to CSRE, 2006, although international comparisons are difficult). Children with immigration background are more than 3 times as likely to be placed in such schools or classes as native children, even if participation in special needs classes specifically designed to help pupils overcome language barriers is not counted (OFS, 2009a). The evidence indicates that integration of children with learning difficulties in mainstream classes and schools raises their education outcomes, especially in the case of children with immigration background, and that integrative support measures are less costly (Vollacott and Wolter, 2005; CSRE, 2006). Placement of children in separate schools and classes for children with learning difficulties or disabilities should be further reviewed, notably with respect to children with immigration background, who are overrepresented. According to a new nationwide framework (inter-cantonal Concordat), the cantons have specified a catalogue of education services that cantons will be required to offer for free to children and young people with special education needs up to the age of 20. The Concordat specifies that integrated education should be preferred to the separation of pupils in special needs classes or schools. It has been ratified in six cantons and is scheduled to become law in 2011 if at least 10 cantons approve it.

18. The evidence on peer effects is not yet conclusive, as available data sets have, for the most part, not yet allowed the resolution of estimation issues (such as self selection and simultaneity, see the review in Nechyba, 2006). Recent studies, which resolve estimation problems to some extent, include Hanushek et al. (2003) who report that students whose performance is rated in the upper quartile are not affected by performance of other pupils, in contrast to performance in the lower quartiles.

19. Defined as a different nationality or a different mother tongue. 


\section{... and has a strong influence on subsequent education pathways}

Almost all pupils attending schools with basic demands and who subsequently move on to upper secondary degrees do so in the vocational education system. By contrast, one half of pupils graduating from a school with extended demands move on to the lycée, which prepares for university. Pupils in schools with basic demands find it difficult to move on to a lycée even if they attain very high levels of competency (as measured by PISA test scores). For example, pupils having obtained the highest score level category on PISA have a probability of more than $80 \%$ to move to a lycée if they attended a school with extended demands, whereas this probability is below $50 \%$ if such a pupil attended the school with basic requirements. For a medium competency level the probability is 5 times higher for a pupil who has attended a school with extended demands (CSRE, 2006). These results suggest that mobility across school types is insufficient to ensure that all pupils with high competency have equal access to upper secondary tracks preparing for entry into tertiary academic education. Indeed, the type of school is a stronger predictor for the subsequent educational pathways taken than the competency level. The impact of parental education background on the probability of entering dual vocational training rather than full-time schooling $^{20}$ is high, and this impact is strongly intermediated by the selection into schools at the lower secondary education level. ${ }^{21}$

In sum, tracking in the secondary schooling is not effective in giving all pupils with high competency levels access to tracks preparing for tertiary academic education. The difficulties in assigning pupils to different tracks according to their competency level consistently across the country impairs the selection of students into higher education. The probability of a pupil with a modest socio-economic background aspiring to enter tertiary academic education, relative to a pupil with relatively favourable socio-economic background, is lower than in almost all OECD countries. While some other countries with selective lower secondary school systems (Germany, Hungary, the Slovak Republic) also display very low odds, in Switzerland the odds remain unusually low even when the odds are computed for a given point score on the PISA scale of mathematics (OECD, 2007c).

In response to the inequities generated by early selection in lower secondary education, the HarmoS concordat proposes to postpone the age of first selection to 13 years in all cantons. Many cantons have already done so, although in 3 of them first tracking still occurs at age 11 . Several cantons have also decided, over the past decade (e.g. the canton of Zurich), to introduce school systems that combine a smaller number of tracks with streaming inside the class for each subject. There is evidence that these newly introduced school types have encouraged upward mobility of pupils during lower secondary school (CSRE, 2006). Some are also offering comprehensive schooling as an alternative to tracked schools, although this step may in effect raise the number of tracks in lower secondary education.

\section{Policy reforms are underway in tertiary academic education ${ }^{22}$}

The university education system is diverse in its institutional structure. Universities (hautes écoles universitaires) comprise the 2 Federal Institutes of Technology (instituts féderaux de technologie), funded and supervised by the federal government, as well as 10 cantonal universities, mostly funded and fully supervised by the cantons. The maturité degree gives unconditional access to most degree courses in these institutions. In addition, the universities of applied science, which are also mostly funded by the cantons,

20 These include the lycées as well as the écoles de culture génerale (see Annex).

21. See Hupka, Sacchi and Stalder (2006).

22. Tertiary academic education refers to the universities and universities of applied science (both are classified as ISCED 5A). 
but, unlike the universities, are subject to federal regulation, offer access to tertiary academic education through upper secondary vocational education (see Boxes 1 and 2).

\section{The reputation of Swiss universities benefits from a high level of resources and well-developed autonomy}

Swiss universities rank highly in terms of research output and the research reputation of staff. The number of publications relative to population is large in international comparison (OECD, 2006a) and international rankings of universities - such as the Shanghai Jiao Tong University Academic Ranking of the World - show that many achieve relatively high placements in comparison to the average performance, in per capita terms, of other national university systems in the OECD (see, for example, Aghion et al., 2007 for an international comparison) ${ }^{23}$ Hence, most Swiss university students are enrolled in an institution with high international reputation (although this is not true for the universities of applied science).

Universities are autonomous with respect to staffing decisions and the allocation of funds. This, alongside resource levels, has contributed to the research reputation of Swiss universities, in comparison to other OECD countries. Indeed, empirical evidence shows that university autonomy as well as competition among universities for funds interact with each other to improve research output of universities. Nonetheless the drop-out rate of about $30 \%$ is high in view of the relatively low entry rate and a selective upper secondary education system. The drop-out rate seems to decrease with the introduction of the twotier degree structure according to the principles of the Bologna Process (OFS, 2009).

\section{Current reform efforts address segmentation of the higher education system}

The segmentation of institutions into different types with different and often highly local policy responsibilities have lead to fragmentation in the past, raising costs by favouring provision by sometimes small departments (OECD 2003, 2006a). This contributed to long study duration, which reached 6 years for university graduates in $2007 .{ }^{24}$ Differences in study duration, even for the same degrees across subjects, are still large even though these differences have diminished at the universities since the adoption of the two-tier degree structure.

Reforms, which are still in the process of implementation (Box 3), are seeking to overcome fragmentation, by subjecting the different types of institutions to common regulation and funding principles, shared by cantons and the federal government. The draft law foresees the creation of an independent accreditation agency, which will introduce institutional accreditation of universities and universities of applied science according to coherent criteria, and more strongly output-oriented funding principles. Indeed, a mix of input and output-oriented funding principles, as foreseen, may be best-suited to foster cost-effectiveness. Enrolment is a useful criterion if student mobility is strong and creates pressure to improve quality. An external validation of internal quality assurance mechanisms, as the reform aims for, seems the most appropriate for education systems experienced in evaluation (OECD, 2008c).

An important reform step already taken is the establishment of uniform cost accounting across universities and universities of applied science which has allowed comparisons of the cost of obtaining similar degrees across institutions. The accounting system has served as a basis for establishing cost

23. The Shanghai index is based on a range of criteria focussing on published research output in the sciences, engineering and mathematics as well as the presence of faculty staff and alumni with prestigious prices and strong publication performance. See Aghion et al (2007), who rank countries' university systems by summing inverted ranks in the index.

24. In the one-tier degree structure which is being phased out. In the new dual degree structure, students take 4.2 years to complete a first degree and most move on to a master's, which takes $1 \frac{1}{2}$ to 2 years to complete. 
benchmarks per study year. The draft law foresees that the cost benchmarks ("reference costs") will be used to determine the federal co-funding for cantonal universities and the universities of applied science (Box 3).

\section{Box 3. Reform of universities and universities of applied science}

The recent constitutional amendment (Box 1) requires the confederation and the cantons to coordinate their policies towards tertiary academic education. Draft legislation foresses that the hitherto separately regulated universities and universities of applied science will be subject to a common regulatory framework. It proposes the creation of new institutions to ensure common decision-making. If the legislation is approved by parliament the new institutions include the following:

- The conference of universities and universities of applied science (conférence des hautes écoles) meets in two forms. The plenary conference (conférence plénière), which will consist of representatives of all cantons and of the confederation, will set funding conditions, including the rules underlying the reference costs, The council of university institutes (conseil des hautes écoles) which consists of representatives of all jurisdictions in charge of tertiary academic institutions (the confederation and 14 cantons), will determine, inter alia, framework conditions for course structure and accreditation procedures. In particularly costly education programmes, it will take direct decisions about the assignment of teaching duties across institutions.

- A rectors' conference of universities and universities of applied science, in charge of preparing and implementing the conference's decisions.

- The council for accreditation will include representatives of universities, the social partners, students as well as higher education policy experts. It will take independent decisions on accreditation of institutions and programmes, supported by an agency, and regulates the rules governing accreditations on quality assessment and accreditation.

Quality assurance will rely on internal mechanisms developed by the institutions. The accreditation process foresees providing a review of the adequacy of these mechanisms. The contributions of the federal government to the basic funding of education services from cantonal universities and universities of applied science will be based on reference costs. The confederation will fund $20 \%$ of reference costs at the cantonal universities and $30 \%$ at the universities of applied science. Reference costs are calculated on the basis of average costs across institutions offering the same degree for each study year completed by enrolled students (subject to an absolute limit on years of study). The federal government transfers will also take into account a mix of input and output indicators - in particular the number of students and graduations, the average duration of studies, the teacher-student ratio and the disciplines chosen by students Students' cantons of origin will make transfers covering a substantial share of the remaining reference cost component (after deduction of any student fees).

A cantonal concordat is planned to determine the rules for the funding of cantonal universities and universities of applied sciences, especially with respect to students who study in a different canton than their canton of origin. An agreement between the federal government and the cantons is also necessary to introduce the new framework.

Funding principles in tertiary academic education could be improved further

Competition for funding among universities and universities of applied science depends in part on mobility of students. This point is further reinforced by the fact that the share of university funding allocated through competitive bids on a national basis is limited to bids for research projects. However, mobility of students is low (Oliveira-Martins et al., 2006). In part this is because the mutual recognition of credits for coursework across cantons is underdeveloped. The low volume of cantonal loans and grants (see further below) also contributes to the lack of mobility, especially in view of the unusually high housing costs in Switzerland (see OECD, 2009b). Many students therefore prefer to live with their parents and 
attend the institution closest to home. The mobility of students should be fostered, including through better recognition of course credits across universities.

Since the reference costs will be determined with data from all institutions, they will help generate incentives to reduce costs, as federal co-funding for each university or university of applied sciences does not need to rely on each institution's own costs or inputs. Average cost comparisons in 2004 revealed significant differences between universities in the cost of a degree, with the most expensive degrees in the natural sciences being 50\% costlier than the least expensive (ECRS, 2006). Costs have since converged significantly. To achieve cost reductions, universities have co-operated more intensely in the provision of education, for example through joint specialised master degrees. Nonetheless, the mixed funding arrangements, with large contributions from both the confederation and transfers from canton of origin of the student, may generate inefficiencies. In particular once mobility of students across cantons has risen, a substantial part of study cost per student at cantonal universities and universities of applied sciences will not be born by the canton providing education. These cantons could maintain inefficient facilities, whose costs exceed the reference cost, at a relatively small cost to them. Maintaining such inefficient facilities would in turn raise reference cost and thereby cost throughout tertiary academic education. Particular attention will therefore have to be paid to ensuring that inefficient facilities are in fact closed.

The fees charged to Swiss students by most universities are below CHF 1500 per year. Fees are higher in some universities of applied science, reaching up to CHF 2400 and for tertiary vocational education, where they reach CHF 8000 and more (see also Höckel $e$ al., 2009), depending on the type of institution. While tertiary vocational students pay a significant share of the cost of their education, students in tertiary academic education finance a negligible share.

Grants and government loan schemes for students fall under cantonal competence. $84 \%$ of students in universities and universities of applied science do not receive any financial support from the government, neither through grants nor through loans. Less than $2 \%$ receive government-sponsored loans. CHF 280 million are disbursed for grants per year, while loan disbursements amount to CHF 30 million. Both loan schemes and grants are subject to tests on income and wealth, and, for both types of aid, the amounts disbursed are meant to fill the gap between, on the one hand, the resources parents and the students themselves can provide and the actual cost of study on the other hand. An inter-cantonal agreement is in the process of being adopted and will set common standards for means tested support to students. If adopted, it will allow disbursement of one third of the financial support in the form of a loan.

The lack of government-sponsored loan schemes limits the share of the costs of education that can be financed privately through student fees. Raising the private share of funding is desirable on both efficiency and equity grounds, especially in view of the high private returns to tertiary education. Government-sponsored loan schemes can increase the proportion of study cost born by students while avoiding any discouraging effects on risk-averse prospective students by making repayments contingent on income, similar to a tax. Moreover, such loan schemes could remove financial access barriers if they also help cover living expenses. Detailed empirical evidence on the impact of raising fees for study at universities, accompanied by the introduction of government-sponsored loan schemes in which repayments are tied to the level of income attained once students have graduated is available for Australia. It shows that this policy has allowed widening access to university education by mobilising private funds, while the higher fees did not alter the composition of the studentship to the disadvantage of students with modest socio-economic background (Chapman, 2006). By alleviating precarious financial conditions for some students, which appear to raise study duration significantly (CSRE, 2006, and references therein) government-sponsored student loans could also help lower study duration. In some countries, such loan schemes have been geared further towards providing incentives to raise cost-effectiveness, by turning a fraction of such loans into grants if study duration does not exceed specified limits (OECD, 2008c). At the same time, continued access to grants for students from the most disadvantaged backgrounds should be 
ensured. Among these students, information about the benefits of higher education is likely to be particularly scant (see e.g. OECD, 2008c).

Tuition fees in tertiary academic education should be raised, and government-sponsored loans to students should be made widely available, including for tertiary vocational degree courses, coupled with income-contingent repayments. Higher fees for tertiary academic education would also help avoid the risk that geographic externalities generate disincentives for cantons to fund tertiary academic studies for their graduates from upper secondary education when such studies are economically beneficial. Such externalities may result from students living in a different canton than their canton of origin upon graduation after they start to work. In particular, cantons which fund additional students in tertiary academic education are likely to require higher tax rates, other things equal, whereas cantons use low tax rates to attract highly-qualified workers, including tertiary graduates. Such disincentives could affect cantonal policies upstream in lower and upper secondary education. Moreover, they reinforce the equity case in favour of higher student fees, coupled with government loans tied to income-contingent repayments. 


\section{Bibliography}

Aghion, P, M. Dewatripont, C. Hoxby, A. Mas-Colell, and A. Sapir (2007). "Why Reform European Universities", Bruegel Policy Brief No. 2007-04.

Arvanitis, S., T. Bolli and M. Wörter (2009): Vocational Education and Productivity in the Swiss Business Sector - An Analysis Based on Firm-level and Industry-level Panel Data, Study Mandated by the OECD Economics Department. KOF Konjunkturforschungsstelle Forschungsberichte No. 1648. Swiss Federal Institute of Technology, Zurich.

Clotfelter, C.T., H.F. Ladd and J.L. Vigdor (2007), "How and Why Do Teacher Credentials Matter for Student Achievement?", NBER Working Paper, No. 12828.

Eidgenössische Kommission für Migrationsfragen (2009), Frühförderung - Empfehlungen der Eidgenössischen Kommission für Migrationsfragen, Bern.

Eidgenössische Koordinationskommission für Familienfragen BKFF (2008), Familien- und schulergänzende Kinderbetreuung, Bern.

Hanushek, E., J. Kain, J. Markman and S. Rivkin (2003), “Does peer ability affect student achievment?", Journal of Applied Econometrics, Vol. 18 (5), pp. 527-544.

Hanushek, E.A and S.G. Rivkin (2006), “Teacher Quality”, Handbook of Education Economics, ElsevierNorth Holland, Amsterdam, Chapter 18, pp. 1051-1078.

Hanushek, E. A., and L. Wößmann (2005), "Does Educational Tracking Affect Performance and Inequality? Differences in Differences Evidence across Countries", Working Paper No. 11124, National Bureau of Economic Research, Cambridge, MA.

Heckman, J. J. and D. V. Masterov (2007), "The productivity Argument for Investing in Young Children”, Working Paper No. 13016, National Bureau of Economic Research, Cambridge, MA.

Hoeckel, K., S. Field and W. N. Grubb (2009), Learning for Jobs, OECD Policy Reviews of Vocational Education and Training.

Hupka, s., S. Sacchi and B. E. Stalder (2006), Herkunft oder Leistung? Analyse des Eintritts in eine zertifiziernede nachobligatoische Ausbildung anhand der Daten des Jugendlängsschnitts TREE. Mimeo, Bern.

Ludwig, V. and F. Pfeiffer (2005), Abschreibungsraten allgemeiner und beruflicher Ausbildungsinhalte ZEW Discussion Paper No. 05-36, Mannheim (Germany).

Nechyba, T. (2006), "Income and Peer Quality Sorting in Public and Private Schools", in Handbook of Education Economics, Elsevier-North Holland, Amsterdam, Chapter 22, pp. 1327-1368. 
Nusche, D. (2009), What Works in Migrant Education? A Review of Evidence and Policy Options $O E C D$ Education Working Paper No. 22

OECD (2003), Tertiary Education in Switzerland, Paris.

OECD (2005), Teachers Matter, Paris.

OECD (2006a), Economic Survey of Switzerland, Paris.

OECD (2006b), Economic Survey of Germany, Paris.

OECD (2006d), Starting strong II: early childhood education and care, Paris.

OECD (2007a), Economic Survey of Switzerland, Paris.

OECD (2007b), PISA 2006, Data Vol. 2, Paris.

OECD (2007c), No more failures, Ten steps to equity in education, Paris.

OECD (2008a), Education at a Glance. Paris.

OECD (2008b), Economic Survey of Germany, Paris.

OECD (2008c), Tertiary Education for the Knowledge Society, Paris.

OECD (2009a), Growing unequal, Paris.

OECD (2009b), Economic Survey of Switzerland, Paris.

Office Fédérale de Statistique (OFS, 2008a), Hochschulabsolventen und Hochschulabsolventinnen auf dem Arbeitsmarkt Erste Ergebnisse der Längsschnittbefragung 2007.

Office Fédérale de Statistique (2008b), Die soziale Dimension an den Hochschulen. Die Schweiz im europäischen Vergleich. Neuchâtel, 2008.

Office Fédérale de Statistique ( 2009a), Bildungssystemindikatoren. Neuchâtel, 2009. www.ofs.ch.

Office Fédérale de Statistique (OFS, 2009b), Hochschulsystem - Tertiärstufe Hochschulen - Daten, Indikatoren. www.ofs.ch.

OFS (2009c): Bologna-Barometer 2009. Neuchâtel.

OFS (2004) Schulen und Bildungswege der Sekundarstufe II in der Schweiz.

Office Fédérale de Statistique/Conférence Suisse des Directeurs Cantonaux de l'Instruction Publique (OFS/CDIP, 2009), PISA 2006: études sur les compétences en sciences. Neuchâtel.

Oliveira Martins, J. et al. (2007), "The policy determinants of tertiary education", OECD Economics Department Working Paper, No. 576, September.

Piketty, T. and Valdenaire, M. (2006), “L'impact de la taille des classes sur la réussite scolaire dans les écoles, collèges et lycées français", Ministère de l'Éducation Nationale, Les dossiers No. ${ }^{\circ} 173$, Mars. 
Pont, B., B. Nusche and D. Hopkins (2008), Improving School Leadership: Case Studies and Concepts for Systemic Action, OECD, Paris.

Stadelmann-Steffen, I. Stamm, M. (2009), Frühkindliche Bildung in der Schweiz, Commission Suisse pour l’Unesco, Genève.

Coradi Vellacott, M. and S. C. Wolter (2005), Equity in Education Thematic Review. Country Analytical Report. Switzerland. OECD, Paris, 2005.

Wolter, S. C. (2008), Ausbildungskosten und -nutzen und die betriebliche Nachfrage nach Lehrlingen, Perspektiven der Wirtschaftspolitik, vol. 9, pp. 90-108.

Wolter, S. C. and B. Weber (2005), La rentabilité de la formation : un indicateur économique essentiel à l'enseignement. La Vie Économique 2005 vol. 10 pp. 38- 42. 
Annex: The education system in Switzerland

Age

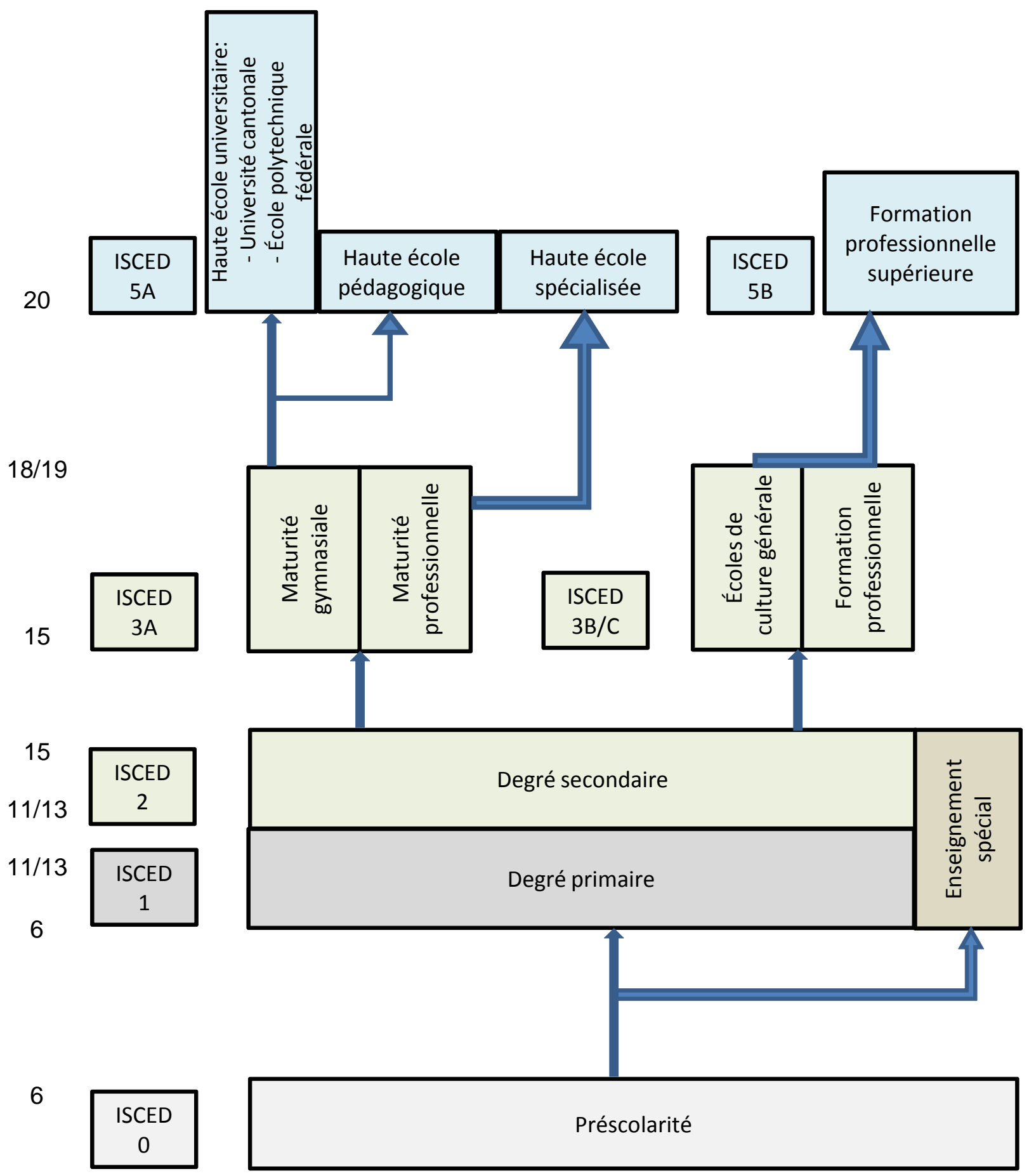


ECO/WKP(2011)7

\section{WORKING PAPERS}

The full series of Economics Department Working Papers can be consulted at www.oecd.org/eco/workingpapers/

837. The Price Responsiveness of Housing Supply in OECD Countries (January 2011) by Aida Caldera Sánchez and Åsa Johansson

836. Housing markets and structural policies in OECD countries (January 2011) by Dan Andrews, Aida Caldera Sánchez and Åsa Johansson

835. Raising potential growth after the crisis: A quantitative assessment of the potential gains from various structural reforms in the OECD area and beyond (January 2011) by Romain Bouis and Romain Duval

834. The GDP impact of reform: a simple simulation framework (January 2011) by Sebastian Barnes, Romain Bouis, Philippe Briard, Sean Dougherty and Mehmet Eris

833. Improving the flexibility of the Dutch housing market to enhance labour mobility (January 2011) by Jens Høj

832. Making the Dutch pension system less vulnerable to financial crises (January 2011) by Jens Høj

831. Real house prices in OECD countries: the role of demand shocks and structural policy factors

(December 2010) by Dan Andrews

830. International financial integration and the external positions of euro area countries (December 2010) by Philip R. Lane

829. Improving fiscal performance through fiscal councils (December 2010) by Robert Hagemann

828. Minimising risks from imbalances in European banking

(December 2010) by Sebastian Barnes, Philip Lane and Artur Radziwill

827. Resolving and avoiding unsustainable imbalances (December 2010) by Sebastian Barnes

826. Current account imbalances in the euro area: a comparative perspective (December 2010) by Sebastian Barnes, Jeremy Lawson and Artur Radziwill

825. Does fiscal decentralisation strengthen social capital? Cross-country evidence and the experiences of Brazil and Indonesia (December 2010) by Luiz de Mello 
824. Fiscal decentralisation and public investment: The experience of Latin America (December 2010) by Luiz de Mello

823. Product market regulation and competition in China

(December 2010) by Paul Conway, Richard Herd, Thomas Chalaux, Ping He and Jianxun Yu

822. Reforming China's monetary policy framework to meet domestic objectives (December 2010) by Paul Conway, Richard Herd and Thomas Chalaux

821. Regulatory reforms to unlock long-term growth in Turkey

(December 2010) by Rauf Gönenç and Łukasz Rawdanowicz

820. After the crisis: mitigating risks of macroeconomic instability in Turkey

(December 2010) by Lukasz Rawdanowicz

819. The 2008-09 crisis in Turkey: performance, policy responses and challenges for sustaining the recovery

(December 2010) by Łukasz Rawdanowicz

818. Fiscal-consolidation strategies for Canadian governments

(November 2010) by Yvan Guillemette

817. The land transport sector: policy and performance

(November 2010) by Jan Persson and Daeho Song

816. A simple model of the relationship between productivity, saving and the current account (November 2010) by Jean-Marc Fournier, Isabell Koske

815. The impact of structural policies on saving, investment and current accounts (November 2010) by Clovis Kerdrain, Isabell Koske, Isabelle Wanner

814. Towards a less distortive and more efficient tax system in Portugal (November 2010) by Alvaro Pina

813. Are global imbalances sustainable? Shedding further light on the causes of current account reversals

(November 2010) by Luiz de Mello, Pier Carlo Padoan, Linda Rousová

812. Turkey's improving integration with the global capital market: Impacts on risk premia and capital costs

(November 2010) by Rauf Gönenç, Saygin Şahinöz, Özge Tuncel

811. Trade linkages in the OECD trade system (October 2010) by Jérôme Brézillon, Stéphanie Guichard and Dave Turner

810. Enhancing the effectiveness of social policies in Indonesia

(October 2010) by Margherita Comola and Luiz de Mello 